\title{
Experimental assessment of a CI engine operating with 1-pentanol/diesel fuel blends
}

\author{
Murat Kadir Yeşilyurt ${ }^{1 *}$, Battal Doğan ${ }^{2}$, Derviş Erol ${ }^{3}$
}

0000-0003-0870-7564, 0000-0001-5542-4853, 0000-0002-3438-9312

${ }^{1}$ Department of Mechanical Engineering, Faculty of Engineering-Architecture, YozgatBozok University, Yozgat, 66200, Turkey

${ }^{2}$ Department of Automotive Technology, TUSAŞ-Kazan Vocational School, Gazi University, Ankara, 06500, Turkey

${ }^{3}$ Department of Automotive Technology, Kırıkale Vocational School, Kırıkkale University, Kırıkkale, 71450, Turkey

\begin{abstract}
Alcohols have been known as influential alternatives for the utilization in the compression-ignition (CI) engines. In contrast to lower-order alcohols such as methanol-C1 and ethanol-C2, long-chain alcohols (higher-order alcohols) have a hopeful future for CI engines. Pentanol-C5 or amyl alcohol, regarding its affirmative chemical and physical properties, is a type of higher alcohol that can be obtained from biomass resources and hence it has to be evaluated as an alternating and sustainable fuel candidate in diesel engine applications. The objective of this work is to explore the engine performance and exhaust emission characteristics of a CI engine running on 1-pentanol/diesel fuel mixtures. For this aim of the experimental research, three different blends were created by infusing various ratios $(10,20$, and $30 \%$ by volume) of 1-pentanol into pure diesel with implementing the splash-blending method to acquire the binary blends of Pt10, Pt20, and Pt30. The tested fuel samples were used in a single-cylinder diesel engine coupled with a generator. The influences of a next-generation alcohol addition to the diesel upon the engine performance along with exhaust emission levels of the tested engine were meticulously researched at six different engine loads $(0,0.4,0.8,1.2,1.6$, and $2 \mathrm{~kW})$ with a stable speed $(3000 \mathrm{rpm})$. The infusion of alcohol into the diesel fuel declined cetane number as well as the lower calorific value of the fuel blends. As a result of the study carried out, it was observed that the brake specific fuel consumption (BSFC) increased between 4.46$11.78 \%$ averagely as the ratio of 1-pentanol in the mixtures increased while brake thermal efficiency (BTE) and exhaust gas temperature (EGT) dropped up to $6.75 \%$ and $6.69 \%$, respectively owing to the lesser energy content of the 1pentanol. When the test engine operating with binary blends, unburned hydrocarbon $(\mathrm{HC})$ and carbon monoxide $(\mathrm{CO})$ emissions were obtained to be higher than that of conventional diesel fuel due to the higher latent heat of vaporization (LHV) of 1-pentanol resulting in a cooling impact in the cylinder, leading descending trend in the efficiency of the combustion. Besides, the addition of 1pentanol to diesel caused the mitigation in smoke emission by 77.37-89.60\%, carbon dioxide $\left(\mathrm{CO}_{2}\right)$ by $13.06-30.83 \%$, and nitrogen oxides $\left(\mathrm{NO}_{\mathrm{X}}\right)$ by 13.43 $41.61 \%$ on an average as compared to diesel fuel. Overall, it has been shown up that 1-pentanol might be successfully utilized as an oxygenated fuel additive to diesel fuel, however in a minimum concentration of 1-pentanol, i.e., Pt10 blend has provided luminous outcomes in terms of mitigating the EGT, smoke opacity, and especiallyNOxemissions, however at the expense of boosting in the emissions of $\mathrm{CO}$ and $\mathrm{HC}$.
\end{abstract}

Keywords: Diesel engine; Emissions; Higher alcohol; 1-Pentanol; Performance

\author{
* Corresponding author \\ Murat Kadir Yeşilyurt \\ kadir.yesilyurt@bozok.edu.tr
}

Address:Department of Mechanical Engineering, Faculty of EngineeringArchitecture, Yozgat Bozok University, Yozgat, 66200, Turkey

Tel:+903542421001

Fax:+903542421005

Research Article

$\begin{array}{ll}\text { Manuscript } & \\ \text { Received } & 24.03 .2020 \\ \text { Revised } & 17.04 .2020 \\ \text { Accepted } & 12.05 .2020\end{array}$




\section{Introduction}

An average of 85 million barrels of oil has been consumed daily due to increasing energy needs in recent years all over the world. The energy consumption speed around the world is about 300 thousand times higher than the speed of the formation of fossil-based fuels [1]. It is estimated that crude oil will be depleted in the next 50 years [2]. Therefore, the researches and development studies have continued for alternative and clean fuels that will replace crude oil. The search for alternative fuels has taken an important place in the world agenda in previous years [3]. The oil embargo declared by the Organization of Arab Petroleum Exporting Countries (OAPEC) against the USA, which supported Israel in the Arab-Israeli War, on October 15, 1973, is known as the Oil Crisis or the 1973 crisis [4]. Since the industrialized countries are the most important customers of oil exporters, this serious crisis has focused the researchers on the seek for alternative energy sources for the first time [5].

Nowadays, the augmentation in the number of motor vehicles has led to a faster depletion of fossil-based fuels with limited resources. Overconsumption of fossil-based fuels has caused oil wars and environmental problems in the world [6]. Global climate change and global warming have been threatening the countries. One of the main reasons for climate change is to be noted the increased usage of fossilbased fuels. Thus, researchers aim to utilize the alternative fuels instead of fossil-based fuels by making direct changes to fuel and without making too many changes in fuel systems [7-9]. Liquefied petroleum gas (LPG), Compressed natural gas (CNG), Alcohol-based fuels, Biodiesel, Biogas, and Hydrogen are used as alternative fuels instead of fossilbased fuels in vehicles powered by the internal combustion engines $[10,11]$. In order to prefer a fuel as an alternative, a) it should not require too many changes in the fuel systems of the engine, $b$ ) it should not cause an excessive decrease in performance, c) it should decrease exhaust emissions, and d) it should be economically affordable [12].

Dropping the levels of air pollution all over the world is complicated and therefore, it requires some factors like awareness of humans, progress in the technology, and policy precautions. Some of the Eastern European countries have recommended limitations or even the forbid of the use of the vehicles powered with diesel engines, at least for light vehicles so as to decrease the levels of air pollution along with ensuring the low and ultra-low emission regions in the cities after the emission scandal in particular $[13,14]$. It can be stated that many European countries, nonetheless, depend on fossil-based fuel sources heavily. There is still a long road in advance to attain low carbon energy systems even though the endeavors and alterations in the energy policies implemented by European countries [15]. Dey et al. [16] reported that prohibiting older cars, prohibiting new vehicles having diesel engines, rising the tax of the diesel consumption, altering the motor tax to the prior engine capacity-based approximation have been effectual preventions for decreasing the influences considerably. However, abandon from diesel engines is not feasible in the near future due to the systems where high power is required such as heavy-duty vehicles, agricultural machines, power generation stations, etc. From this perspective, in the recent years, great progress has been made in diesel engine design and technology [17]. It has been noted by the majority of the researchers that the releasing of air pollutants from internal combustion engines may generally mitigate if alternative and clean fuels have been used instead of fossil-based pure diesel in these engines [18-20].

Biodiesel is an environmentally friendly and renewable fuel within the scope of biofuels that can be synthesized from comestible or non-comestible vegetable oils (canola, sunflower, safflower, cottonseed, mustard, soybean, etc.) and animal fats with the help of various chemical methods like dilution, pyrolysis, micro-emulsion, transesterification, etc. [21, 22]. The fact that biodiesel freezes faster, its properties such as high viscosity, the tendency to oxidation, and low energy content, and that it causes the increase of $\mathrm{NO}_{\mathrm{X}}$ in exhaust emissions have led to problems in its direct use as an alternate fuel in the diesel engines [23-25]. Therefore, researchers have recommended using alcohol with better fuel characteristics and higher carbon chains as alternative fuels to solve these issues [10, 26, 27].

Ethyl and methyl alcohols have been known as the utmost surveyed and preferred alcohols as alternative fuels in the literature. For instance, Can et al. [28] looked into the influences of ethyl alcohol infusion (10\% and 15\% v/v) into No. 2 diesel on the emission and performance behaviors of a turbocharged indirect-injection (IDI) diesel engine under diverse pressures for injection like $150 \mathrm{bar}, 200 \mathrm{bar}$, and 250 bar. The researchers indicated that the alcohol addition dropped the sulfur dioxide $\left(\mathrm{SO}_{2}\right)$, soot, and $\mathrm{CO}$ emissions even though it led to an augmentation in $\mathrm{NO}_{\mathrm{X}}$ emission. The engine power decreased by pretty much $12.5 \%$ in $10 \%$ ethanol fraction and $20 \%$ in $15 \%$ ethanol fraction. Also, the increase of the fuel injection pressure in the engine fueled with diesel/ethanol mixtures caused declining smoke and $\mathrm{CO}$ as compared to diesel. Özgür et al. [29] analyzed the emissions, performance, and efficiency of a CI engine powered by ethanol/diesel blend which contains $20 \%$ ethanol on a volume basis. The experiments were carried out between 1000-2600 rpm engine speed. According to the results, specific fuel consumption, and $\mathrm{NO}_{\mathrm{X}}$ emission augmented regarding the usage of diesel/alcohol blend while power, torque, and $\mathrm{CO}$ emission reduced. Besides, the alcohol addition to diesel allowed descending in both energy and exergy efficiencies. Khoobbakht et al. [30] executed the exergy and energy analysis of a CI engine running with the ternary mixtures of biodiesel, ethanol, and diesel fuel exerting central composite rotatable design of response surface methodology. The researchers found that $0.08 \mathrm{~L}$ etha- 
nol/0.17 L biodiesel/1 L diesel blend showed the most exergy efficiency under the load of $94 \%$ with the speed of $1900 \mathrm{rpm}$. At the aforementioned conditions, the highest energy and exergy efficiency values were calculated to be as $36.61 \%$ and $33.81 \%$, respectively. Interestingly, Chen et al. [31] performed on the emission and combustion features of a common-rail diesel engine fueled with the mixtures of diesel, n-pentanol, and methanol at different loads. The experimental results presented that the ignition delay extended, the period of combustion reduced, and the maximum temperature of the combustion process rose with the ascending of methanol concentration in the sample. In addition, the methanol addition caused to descend in soot intensity while the turn up in the emission of $\mathrm{NO}_{\mathrm{x}}$. Duraisamy et al. [32] conducted comparative work on methanol/polyoxymethylene dimethyl ethers and methanol/diesel dual blends upon the reactivity controlled CI burning features in an automotive engine having three-cylinder, fourstroke, and turbocharged properties under 3.4 bar brake mean effective pressure with $1500 \mathrm{rpm}$ speed. The researchers were to be noted that brake specific oxides of nitrogen and soot emissions were substantially mitigated for both of the dual fuel with the increase in methanol mass fraction meanwhile $\mathrm{CO}$ and $\mathrm{HC}$ profiles were vaguely gone up. Pedrozo et al. [33] examined a lean-burn strategy of the combustion for diesel/ethanol blend to increase the efficiency and to go down the exhaust pollutants of the tested engine at a fixed speed (1200 rpm) along with different loading conditions from 0.3 to $2.4 \mathrm{MPa}$ net indicated mean effective pressure (IMEP). Consequently, the findings coming from the experiments exhibited that dual-fuel combustion strategy by using a fuel involving low carbon like ethanol was a powerful aspect of declining the dependency on conventional diesel fuel and incorporated greenhouse gas emissions. Al-Esawi et al. [34] investigated the influence of ethanol/biodiesel/diesel ternary mixtures on some of the fuel characteristics. They observed that the blend of $18 \%$ soybean oil methyl ester, $5 \%$ ethanol, and $80 \%$ diesel resulted in a little alteration in cetane number, calorific value, viscosity, and droplet lifetime in comparison with the pure diesel fuel by $0.2 \%, 2.2 \%, 2.0 \%$, and $1.2 \%$, respectively.

The number of carbon atoms for alcohols determines their physical and chemical properties. The boiling point of alcohol is much higher compared to hydrocarbons, which have an equal number of carbon atoms because they contain hydrogen bonds between their molecules. Since alcohols contain one or more oxygen atoms, their combustion heat is lower. While methanol is produced from coal and petroleum derivatives, ethanol is obtained from biomass through fermentation process $[35,36]$. Since methanol possesses a very restricted solubility characteristic inside of diesel, ethanol has been the most commonly used alternative fuel. In addition, ethanol has been easily exploited in both sparkignition and $\mathrm{CI}$ engines out of any major modification on the engines. According to researches, when 5-30\% ethanol is added to pure diesel fuel, there are enhancements in fuel consumption and detracts in engine power [37, 38]. Besides that, ethanol causes combustion problems in engines because of its low flash point, boiling point, and viscosity properties.

Particle matter emissions have decreased when using oxygenated fuel additives as fuel in diesel engines. It is very important to use alcohol for reducing the pollutant emissions released from the engines to the environment [39]. However, it is not possible to use alcohols directly due to various fuel characteristics, especially the lower cetane number. The shaping of the fuel concoction, as well as combustion, occur simultaneously in diesel engines. The droplets that form the fuel blend in the consequence of spraying and the fuel/air mixture is not distributed homogeneously in the combustion chamber of the $\mathrm{CI}$ engine. For this reason, it does rather hard to create a homogeneous mix in diesel engines [40]. Actually, alcohols may be used by blends with pure diesel fuel with certain proportions without the need for modification in diesel engines. The alcohol that will form a mixture with diesel fuel must be dissolved in fuel at any rate and the stability of the mixture has to be ensured in all weather conditions.

Pentanol is a type of alcohol having five carbon atoms in its chemical structure, the molecular formula of which is $\mathrm{C}_{5} \mathrm{H}_{11} \mathrm{OH}$. It has a moderate odor along with a colorless liquid. Its density is less than that of water [41, 42]. According to the physical properties of pentanol given in Table 1 , it can be presumed to be an important additive to diesel amongst all mentioned alcohols.

Cetane number is an indication that shows the selfignition quality of diesel fuel. A fuel with a high cetane number can ignite easily and burn quickly in the chamber of combustion. The cetane number of pentanol is upward than that of methanol and ethanol, as represented in Table 1 [46, 47]. The LCV, which is the energy amount indicator of the fuels used in the engines, is desired to be high. The LCV of pentanol is approximately $20 \%$ lower than that of traditional diesel because it contains oxygen [48].Pentanol has a higher evaporation temperature than ethanol and methanol. Therefore, the evaporation and mixing of air with fuel are slower. High viscosity and density cause the fuel not to be atomically sprayed from the injector as anticipated $[49,50]$. This case extends the ignition delay period that influences the reaction of the combustion taking place in the cylinder and causes poor combustion reaction. The density and viscosity values of pentanol are closer to diesel fuel than other alcohols. However, there are fewer studies on pentanol in the recent literature. A part of them have been summarized as follows: Ağbulut et al. [51] researched experimentally the utilization of fusel oil (isoamyl alcohol), that is one of the isomers of the pentanol, with diesel in a CI engine at four dissimilar loads $(2.5,5.0,7.5$, and $10 \mathrm{Nm})$ and at 2000 rpm engine speed.The researchers observed that the emissions of $\mathrm{NO}_{\mathrm{x}}$ and COremarkably descended down to $20 \%$ 
Table 1. Technical characterization of diesel and various alcohols [39, 43-45]

\begin{tabular}{clcccccc}
\hline No & Properties & Unit & Methanol & Ethanol & Butanol & Pentanol & Diesel \\
\hline 1 & Chemical formula & - & $\mathrm{CH}_{3} \mathrm{OH}$ & $\mathrm{C}_{2} \mathrm{H}_{5} \mathrm{OH}$ & $\mathrm{C}_{4} \mathrm{H}_{9} \mathrm{OH}$ & $\mathrm{C}_{5} \mathrm{H}_{11} \mathrm{OH}$ & $\mathrm{C}_{\mathrm{x}} \mathrm{H}_{\mathrm{y}}$ \\
\hline 2 & Molecular weight & $\mathrm{g} / \mathrm{mol}$ & 32.04 & 46.07 & 74.12 & 88.15 & $190-211.7$ \\
\hline 3 & Carbon & wt. $\%$ & 37.48 & 52.14 & 64.82 & 68.18 & 86.13 \\
\hline 4 & Hydrogen & wt. $\%$ & 12.48 & 13.02 & 13.49 & 13.61 & 13.87 \\
\hline 5 & Oxygen & wt. $\%$ & 49.93 & 34.73 & 21.59 & 18.15 & 0 \\
\hline 6 & Density at $15^{\circ} \mathrm{C}$ & $\mathrm{kg} / \mathrm{m}^{3}$ & 791.3 & 789.4 & 809.7 & 814.8 & 835 \\
\hline 7 & Viscosity at $40{ }^{\circ} \mathrm{C}$ & $\mathrm{mm}^{2} / \mathrm{s}$ & 0.58 & 1.13 & 2.22 & 2.89 & 2.72 \\
\hline 8 & Flash point & ${ }^{\circ} \mathrm{C}$ & $11-12$ & 17 & $35-37$ & 49 & $>55$ \\
\hline 9 & Boiling point & ${ }^{\circ} \mathrm{C}$ & 647 & 78.3 & 117.5 & 137.9 & $180-360$ \\
\hline 10 & Self-ignition temperature & ${ }^{\circ} \mathrm{C}$ & 463 & 420 & 345 & 300 & $254-300$ \\
\hline 11 & Lower calorific value $(\mathrm{LCV})$ & $\mathrm{MJ} / \mathrm{kg}$ & 19.58 & 26.83 & 33.09 & 34.65 & 42.49 \\
\hline 12 & Cetane number & - & 5 & 8 & 17 & $18.2-20$ & 52 \\
\hline 13 & Solubility & $\mathrm{g} / \mathrm{L}$ & Miscible & Miscible & 77 & 22 & Immiscible \\
\hline 14 & LHV & $\mathrm{kJ} / \mathrm{kg}$ & 1162.64 & 918.42 & 585.40 & 308.05 & $270-375$ \\
\hline
\end{tabular}

along with rising the proportion of the alcohol inside the binary blend while $\mathrm{HC}$ figures increased drastically up to $40 \%$ in comparison with pure diesel. Based on the outcomes, the minimum BSFC and the peak BTE were detected with diesel fuel because of the LCV of diesel that is higher than that of isoamyl alcohol. The highest cylinder gas pressure and heat release rate of alcohol-treated fuel samples were attained to be higher than that of diesel fuel in the meantime the ignition delay duration prolonged with using diesel/alcohol blend contrary to the diesel fuel owing to the fusel oil's cetane number. Campos-Fernández et al. [52] conducted tests for a $\mathrm{CI}$ engine performance operating with the mixtures of long-chain alcohol/diesel, including between $10 \%$ and $25 \%$ 1-pentanol by volume. There was no significant variation in the power, BTE, and BSFC when the tested engine powered by the generality of the abovementioned fuels in place of conventional diesel fuel. Furthermore, the conducted analysis validated insignificant alterations among the mixtures and diesel trials statistically. Accordingly, the researchers reported that 1-pentanol/diesel fuel blends could be taken into consideration to be suitable alternating fuel candidates providing that the emissions and long-term tests can give convenient findings. Santhosh et al. [53] tested 1-pentanol/diesel blends in the CI engine, having a common-rail injection, with the exhaust gas recirculation system so as to appear the emission and performance grades. Experimental findings showed that 30\% 1-pentanol/70\% diesel fuel led to a decline in BTE by $3.8 \%$, a boosting in BSFC by $9.14 \%$, a reduction in $\mathrm{NO}_{\mathrm{x}}$ emission by $16.7 \%$, and an insignificant rise in $\mathrm{CO}$ and $\mathrm{HC}$ emissions at $60 \%$ load. The authors mentioned that up to $30 \%$ higher-alcohol could be evaluated as alternatives to reference fuel though at the expense of performance. Ashok et al. [54] analyzed the impact of n-pentanol with Calophylluminophyllum oil methyl ester on characterizations in the unmodified CI engine. They used higher proportions of n-pentanol (up to $50 \%$ by volume) in the biodiesel. On the other hand, the infusion of up to $30 \%$ n-pentanol to the biodiesel improved BTE by comparison diesel. A higher BTE was obtained with $10 \%$ n-pentanol/90\% biodiesel blend by $27 \%$ that was lower than that of diesel. It was to be noticed that n-pentanol and biodiesel blends generated 33-50\% and 15-43\% decrement in the $\mathrm{HC}$ and $\mathrm{CO}$ emissions, respectively. Moreover, the smoke and $\mathrm{NO}_{\mathrm{x}}$ emissions were observed to be lower for the alcohol added fuel samples when compared diesel. The researchers claimed that $10 \% \mathrm{n}$-pentanol supplementation to biodiesel had preferable characteristics on account of emission as well as engine performance. Sridhar and coworkers [55] investigated the influence of the infusion of 1-pentanol on the emission and performance behaviors of a single-cylinder CI engine fuelled with diesel and biodiesel fuels for six different loads (from 0 to $20 \mathrm{~kg}$ intervals of 4 $\mathrm{kg}$ ). In the light of the experimental results, they indicated that 1-pentanol/diesel or biodiesel blends decreased the $\mathrm{CO}$, $\mathrm{HC}$, and $\mathrm{NO}_{\mathrm{X}}$ concurrently contrary to straight diesel fuel meanwhile a little decline in BTE occurred in the binary blends. Since this investigation was performed only $20 \%$ of 1-pentanol addition to diesel fuel or biodiesel, further experiments were required to obtain the accurate effects of other mixtures $\mathrm{n}$ the performance and emissions profiles. Appavu et al. [56] recommended the diesel fuel/jatropha oil biodiesel/pentanol blend concerning a novel fuel mixture for the $\mathrm{CI}$ engine and researched the performance and emissions at various engine speeds between 1200-2800 rpm. They concluded that the $20 \%$ by volume pentanol addition to diesel fuel/jatropha oil biodiesel caused in lesser smoke, $\mathrm{CO}$ and $\mathrm{NO}_{\mathrm{X}}$ emissions approximately by $32.4 \%, 41.76 \%$, and $27.6 \%$, respectively owing to the excessive quantity of oxygen molecules in the ternary mixtures leading to advance the combustion efficiency in the engine. Since pentanol possesses many advantages against short-chain alcohols, Yılmaz and Atmanli [57] prepared various 1- 
pentanol/diesel fuel blends which included 5\%, 10\%, 20\%, $25 \%$, and $35 \%$ alcohol. The researchers investigated the performance and emission features at several loads $(0,1.5$, 2.25 and $3 \mathrm{~kW})$ with a fixed speed $(2000 \mathrm{rpm})$. To conclude with, 1-pentanol treated fuel specimens have resulted in higher $\mathrm{CO}$ and $\mathrm{HC}$ emissions as compared to diesel by virtue of the higher LHV of 1-pentanol leading a lesser exhaust gas temperature because of the quenching effect. However, the supplementation of 1-pentanol into diesel caused an increase in BSFC meanwhile EGT was positively affected.

It can be noticed from the extensive literature survey that there are restricted studies with respect to the utilization of 1-pentanol in the CI engine applications even though 1pentanol is a type of long-chain alcohol, having better physicochemical characteristics as compared to lower alcohols because of the advantages of pentanol as highlighted above. Therefore, it can be clearly noted that this topic is necessary to be further researches so as to accomplish from these shortcomings placed in the literature. The aim of the present experimental work is to investigate the engine performance and exhaust emission characteristics of a single-cylinder diesel engine felled with straight diesel fuel and 1pentanol/diesel fuel blends in which 1-pentanol is recently accepted as a next-generation alternative and clean fuel substitution. For the aforementioned perspective, 10\%, 20\%, and $30 \%$ by volume of 1-pentanol were blended with traditional diesel in order to achieve Pt10, Pt20, and Pt30 labeled fuel blends, respectively. The engine tests were carried out at fixed engine speed $(3000 \mathrm{rpm})$ with variable loads (from no load to $2 \mathrm{~kW}$ at $0.4 \mathrm{~kW}$ intervals). The experimental outcomes were compared to the reference diesel and discussed with the results of the recent literature works.

\section{Material and Method}

\subsection{Experimental setup}

In experimental studies, there are instrument required for control and operation with 230/400 V brushless synchronous alternator in a generator set with a single-cylinder, naturally aspirated, and direct-injection (DI) diesel engine, the technical features of which were given in Table 2. The loading of the engine has been provided by the resistance module that consumes the electrical energy produced by the generator. In the module, General brand resistors, which have 200 and $1000 \mathrm{~W}$ capacities each of them, were used and the output power was calculated by using the values on the digital display of the integrated ammeter and voltmeters on the setup. In order to get the accurate and stable results, the engine was firstly brought to steady-state conditions by running for a particular time. Experimental studies were carried out for different engine loads by using pure diesel and 1-pentanol/diesel fuel mixtures in the test setup given in
Fig. 1. The impacts of these fuel samples on performance and exhaust emissions were examined.

Experimental studies were first done with $\mathrm{Pt} 0$ (neat diesel); performance parameters and exhaust emission levels were determined, and then tests were continued with Pt10, Pt20, and Pt30 fuels. Before starting the trials, the tested engine and emission measuring device had been checked. The tested engine was initially run for 15 minutes to reach a steady state status. Experimental studies have been performed on the engine brought to operating temperature at a fixed speed (3000 rpm) for six different load values (from 0 to $2 \mathrm{~kW}$ at intervals of $0.4 \mathrm{~kW}$ ) using the test setup given in Fig. 1. Ambient temperature and humidity were constantly checked during the experiments. The temperature value was read from the indicator on the control panel. The temperatures were measured using the $\mathrm{J}$ type TMX-B12F08 model thermocouple, which can measure between $-200{ }^{\circ} \mathrm{C}$ and $800{ }^{\circ} \mathrm{C}$, attached to the exhaust manifold.

Table 2. Technical specifications of the engine and the generator used in the experiment

\begin{tabular}{l|l}
\hline \multicolumn{2}{c}{ Diesel engine } \\
\hline Parameters & Specifications \\
\hline Brand & Katana \\
\hline Model & Km 178 F \\
\hline Number of cycle & 4 \\
\hline Number of cylinder & 1 \\
\hline Continuous power & $6 \mathrm{hp}$ \\
\hline Maximum engine power & $6.7 \mathrm{hp}$ \\
\hline Type of fuel & Diesel fuel \\
\hline Type of ignition & Compression-ignition \\
\hline Type of fuel injection & Direct-injection \\
\hline Engine speed & $3000 \mathrm{rpm}$ \\
\hline Swept volume & $296 \mathrm{~cm}$ \\
\hline Stroke & $62 \mathrm{~mm}$ \\
\hline Bore & $78 \mathrm{~mm}$ \\
\hline Cooling system & Air-cooled \\
\hline Injector nozzle number & 4 \\
\hline Fuel injection pressure & $200 \mathrm{bar}$ \\
\hline Injection timing & $20^{\circ}$ before TDC \\
\hline Intake system & Naturally-aspirated \\
\hline Compression ratio & $18: 1$ \\
\hline & Specifications \\
\hline Parameters & Kama \\
\hline Brand & KDL3500CE \\
\hline Model & $3 \mathrm{~kW}$ \\
\hline Maximum power & $2.7 \mathrm{~kW}$ \\
\hline Continuous power & 1 \\
\hline Voltage & 230 \\
\hline Frequency & $50 \mathrm{~Hz}$ \\
\hline Current & $11.6 \mathrm{~A}$ \\
\hline & \\
\hline \multicolumn{2}{|l}{ Generator } \\
\hline
\end{tabular}




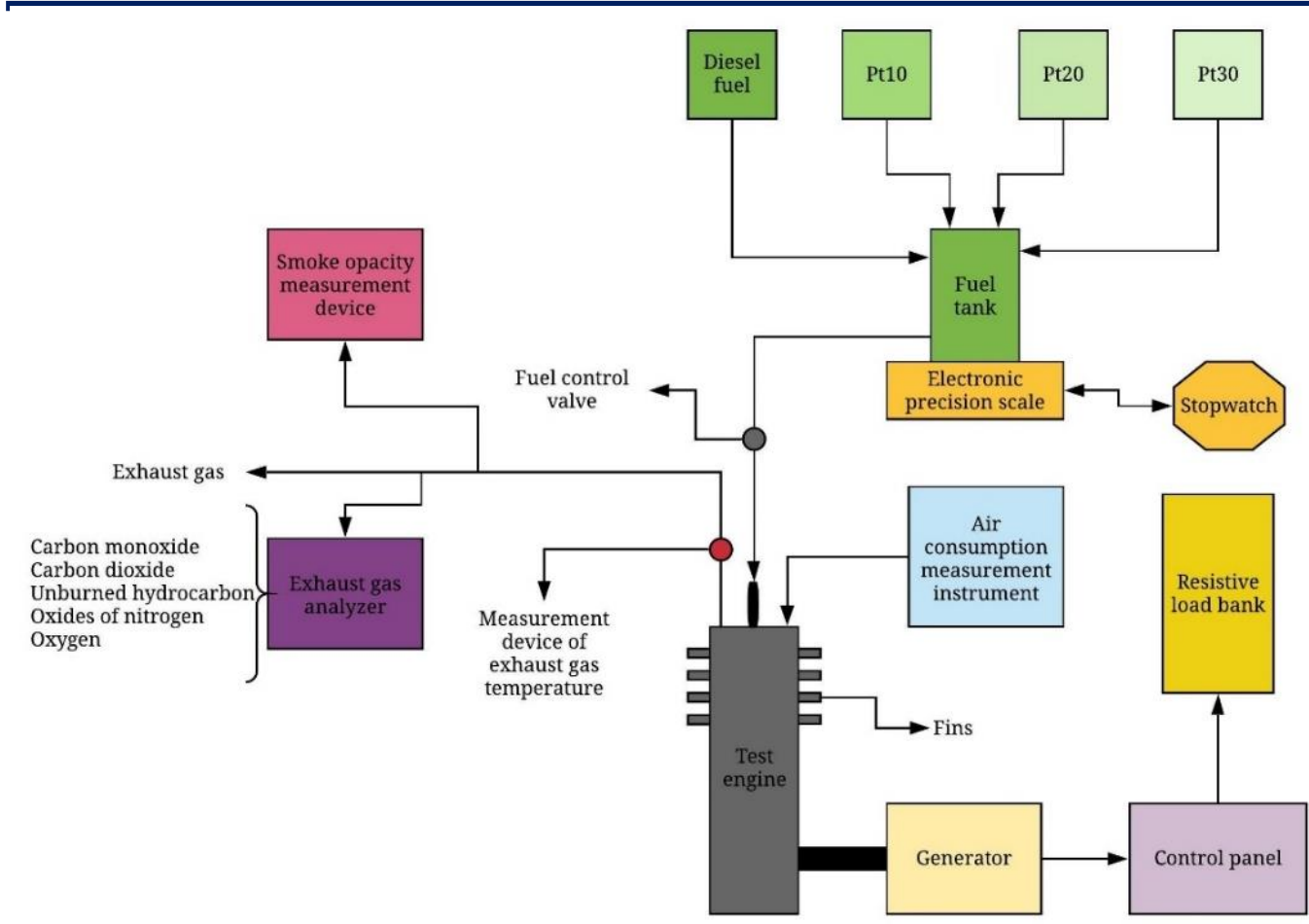

Fig. 1. Schematic layout of the experimental apparatus

The fuel consumption was measured in mass by using the Weithglab brand WH-2002 model electronic precision scale which can measure with an accuracy of $0.01 \mathrm{~g}$ and a digital stopwatch. The fuel tank was emptied and refilled with new tested fuel before each experimental study commence. In addition, the engine was let cool for a certain period of time prior to each new experimental study to prevent measurement errors for performance and exhaust emissions.

Exhaust gas emissions were measured according to the TS 11365-T1 standard by using the Bilsa brand MOD 2210 WINXP-K model exhaust gas analyzer.Information about the measurement range and sensitivity of this device is tabulated in Table 3 .

Table 3. Technical specifications of the exhaust gas analyzer

\begin{tabular}{ccc}
\hline Item & Measuring Range & Accuracy \\
\hline $\mathrm{CO}(\%)$ & $0-10$ & 0.001 \\
\hline $\mathrm{CO}_{2}(\%)$ & $0-20$ & 0.001 \\
\hline $\mathrm{HC}(\mathrm{ppm})$ & $0-10000$ & 1 \\
\hline $\mathrm{NO}_{\mathrm{X}}(\mathrm{ppm})$ & $0-5000$ & 1 \\
\hline $\mathrm{O}_{2}(\%)$ & $0-25$ & 0.01 \\
\hline Lambda $(\lambda)$ & $0-5$ & 0.001 \\
\hline Smoke $(\%)$ & $0-100$ & 0.1 \\
\hline Air/fuel ratio & $5-30$ & - \\
\hline
\end{tabular}

The values of BTE, BSFC, and BSEC for all tested fuels were calculated from Eqs. (1-3) by using the data obtained from the engine tests conducted in experimental studies [ $[58$, 59].

$$
\begin{aligned}
& B T E=\frac{B P}{\dot{m}_{f} x L C V_{f}} \times 100 \\
& B S F C=\frac{3600 x \dot{m}_{f}}{B P} \\
& B S E C=\frac{B S F C \times L C V_{f}}{1000}
\end{aligned}
$$

where,

$\mathrm{BP}(\mathrm{kW})$ : brake power,

$\dot{\mathrm{m}}_{\mathrm{f}}(\mathrm{g} / \mathrm{s})$ : mass flow rate of the fuel,

$\mathrm{LCV}_{\mathrm{f}}(\mathrm{MJ} / \mathrm{kg})$ : lower calorific value of the fuel.

\subsection{Test fuels}

Experimental studies were carried out by using 1pentanol with diesel fuel. The fuel blends were prepared as $10 \%$ 1-pentanol + 90\% diesel fuel (Pt10), 20\% 1-pentanol + $80 \%$ diesel fuel (Pt20), and 30\% 1-pentanol $+70 \%$ diesel fuel (Pt30) by volume. As a result of the examinations and observations, it was determined that phase separation has not been appeared in fuel blends until the end of the experimentations.

Some of the basic fuel properties (density, LCV, and ce- 
tane number) of all tested blends composed of 1-pentanol and diesel have been predicted on account of the Kay's mixing rule technique represented by Lin et al [60] and Atmanli et al. [61]. Furthermore, the kinematic viscosity values of the 1-pentanol/diesel blends were estimated implementing Eq. (5) which was the Arrhenius type mixing rule $[61,62]$.

The Kay's mixing rule and Arrhenius type mixing rule may be mathematically referred as an underneath given forms:

$$
y=\sum_{i}^{n} x_{i} \varphi_{i}
$$

$$
\ln \eta_{b}=\sum_{i}^{n} x_{i} \ln \eta_{i}
$$

where,

$\mathrm{x}$ : concentration of the component,

$\mathrm{y}$ : esteemed property,

$\varphi$ : corresponding property,

$\eta$ : kinematic viscosity.

The main fuel properties for the diesel, Pt10, Pt20, Pt30, and 1-pentanol were tabulated in Table 4.

\begin{tabular}{|c|c|c|c|c|c|c|c|}
\hline No & Property & Unit & Diesel fuel & Pt10 & $\mathrm{Pt} 20$ & $\mathrm{Pt} 30$ & 1-pentanol \\
\hline 1 & Chemical formula & - & $\mathrm{C}_{14} \mathrm{H}_{25}$ & $\mathrm{C}_{13.1} \mathrm{H}_{23.7} \mathrm{O}_{0.1}$ & $\mathrm{C}_{12.2 .2} \mathrm{H}_{22.4} \mathrm{O}_{0.2}$ & $\mathrm{C}_{11.3} \mathrm{H}_{21.1} \mathrm{O}_{0.3}$ & $\mathrm{C}_{5} \mathrm{H}_{12} \mathrm{O}$ \\
\hline 2 & Density $^{1}$ & $\mathrm{~g} / \mathrm{cm}^{3}$ & 0.820 & 0.819 & 0.818 & 0.817 & 0.810 \\
\hline 3 & Kinematic viscosity $^{2}$ & $\mathrm{~mm}^{2} / \mathrm{s}$ & 2.416 & 2.457 & 2.500 & 2.542 & 2.863 \\
\hline 4 & Cetane number & - & 53 & 50 & 46 & 43 & 20 \\
\hline 5 & $\mathrm{LHV}^{3}$ & $\mathrm{~kJ} / \mathrm{kg}$ & $270-375$ & - & - & - & 308.5 \\
\hline 6 & Molecular weight & $\mathrm{g} / \mathrm{mol}$ & 193.0 & 182.52 & 172.03 & 161.55 & 88.15 \\
\hline 7 & $\mathrm{LCV}$ & $\mathrm{kJ} / \mathrm{kg}$ & 43.168 & 42.474 & 41.981 & 40.987 & 34.632 \\
\hline 8 & Carbon & wt. $\%$ & 87.05 & 86.14 & 85.12 & 83.96 & 68.18 \\
\hline 9 & Hydrogen & wt. \% & 12.95 & 12.98 & 13.02 & 13.07 & 13.64 \\
\hline 10 & Oxygen & wt. $\%$ & 0 & 0.88 & 1.86 & 2.97 & 18.18 \\
\hline 11 & Carbon/Hydrogen & - & 6.722 & 6.636 & 6.538 & 6.424 & 4.999 \\
\hline 12 & Copper strip corrosion $^{4}$ & Degree of corrosion & $1 \mathrm{a}$ & $1 \mathrm{a}$ & $1 \mathrm{a}$ & $1 \mathrm{a}$ & - \\
\hline 13 & Assay & $\%$ & - & - & - & - & 99 \\
\hline 14 & Flash point & ${ }^{\circ} \mathrm{C}$ & 60 & 58 & 55 & 40 & 48 \\
\hline 15 & Water content & $\mathrm{ppm}$ & 12 & 90 & 179 & 271 & 858 \\
\hline
\end{tabular}

Table 4. The main fuel properties for the tested fuel samples used in this experimental work

${ }^{1}$ at $15^{\circ} \mathrm{C}$

${ }^{2}$ at $40^{\circ} \mathrm{C}$

${ }^{3}$ These values were adapted from Ref. [39].

${ }^{4} 3 \mathrm{~h}$ at $50^{\circ} \mathrm{C}$

The exact combustion equation of pentanol is given in Eq. (6). Accordingly, the air/fuel ratio for theoretical complete combustion is found to be at 11.7. Since the air/fuel ratio of pure diesel fuel calculated from Eq. (7) is 14.4, the amount of energy to be released under the same conditions will be more for diesel fuel. In other words, it needs to consumes more mixture fuel in mass in order to generate the identical effective power from the engine when compared to pure diesel [63-65]. Oxygen constitutes $34.8 \%$ and $50 \%$ of the

total molecular weight of ethanol and methanol, respectively. The air/fuel ratio for the theoretically complete combustion calculated from Eqs. (8) and (9) of ethanol and methanol is 8.95 and 6.44 , respectively. The amount of oxygen that has no calorific value is high when it burns in the composition of both alcohols. For this reason, air should be well adjusted when using an alcohol-diesel fuel blends in diesel engines.

$$
\begin{gathered}
\mathrm{C}_{5} \mathrm{H}_{11} \mathrm{OH}+7.5\left(\mathrm{O}_{2}+3.76 \mathrm{~N}_{2}\right) \rightarrow 5 \mathrm{CO}_{2}+6 \mathrm{H}_{2} \mathrm{O}+28.2 \mathrm{~N}_{2} \\
\mathrm{C}_{14} \mathrm{H}_{25}+20.25\left(\mathrm{O}_{2}+3.76 \mathrm{~N}_{2}\right) \rightarrow 14 \mathrm{CO}_{2}+12.5 \mathrm{H}_{2} \mathrm{O}+76.14 \mathrm{~N}_{2} \\
\mathrm{C}_{2} \mathrm{H}_{5} \mathrm{OH}+3\left(\mathrm{O}_{2}+3.76 \mathrm{~N}_{2}\right) \rightarrow 2 \mathrm{CO}_{2}+3 \mathrm{H}_{2} \mathrm{O}+11.28 \mathrm{~N}_{2} \\
\mathrm{CH}_{3} \mathrm{OH}+1.5\left(\mathrm{O}_{2}+3.76 \mathrm{~N}_{2}\right) \rightarrow \mathrm{CO}_{2}+2 \mathrm{H}_{2} \mathrm{O}+5.64 \mathrm{~N}_{2}
\end{gathered}
$$




\subsection{Uncertainty analysis}

The accuracy of the measurement apparatus used in the experimental works can be calculated from the analysis of uncertainties of the equipments. In fact, the uncertainties have been principally revealed because of the calibration of the devices, observation by the researcher, environmental conditions, apparatus and system of the experiment progress techniques [66]. From this perspective, the uncertainty values of made use of the instruments in the present study such as exhaust gas emission sensors, temperature sensor, smoke meter, etc. were taken into consideration. Accordingly, it is to be mentioned that the uncertainties of the outcomes coming from the experimentations were predicted with respect to the square root method which were represented underneath $[67,68]$. The percentage uncertainty values of the measured as well as the calculated parameters have been exhibited in Table 5 .

$$
w_{R}=\left[\left(\frac{\partial R}{\partial x_{1}} w_{1}\right)^{2}+\left(\frac{\partial R}{\partial x_{2}} w_{2}\right)^{2}+\cdots+\left(\frac{\partial R}{\partial x_{n}} w_{n}\right)^{2}\right]^{1 / 2}
$$

where,

$\mathrm{R}$ : function of the independent variables,

$\mathrm{x}_{1}, \mathrm{x}_{2}, \ldots, \mathrm{x}_{\mathrm{n}}$ : Independent variables,

$\mathrm{w}_{1}, \mathrm{w}_{2}, \ldots, \mathrm{w}_{\mathrm{n}}$ : Uncertainties of independent variables,

$\mathrm{w}_{\mathrm{R}}$ : Uncertainity of the results.

Table 5. The percentage uncertainty values of the measured as well as the calculated parameters

\begin{tabular}{lll}
\hline No & Item & $\begin{array}{l}\text { Percentage } \\
\text { uncertainty }\end{array}$ \\
\hline 1 & Load & \pm 0.50 \\
\hline 2 & Engine speed & \pm 0.33 \\
\hline 3 & Fuel flow rate & \pm 1.11 \\
\hline 4 & Brake specific fuel consumption & \pm 1.27 \\
\hline 5 & Brake thermal efficiency & \pm 1.26 \\
\hline 6 & Exhaust gas temperature & \pm 0.50 \\
\hline 7 & $\mathrm{CO}$ & \pm 1.17 \\
\hline 8 & $\mathrm{CO}$ & \pm 0.60 \\
\hline 9 & $\mathrm{HC}$ & \pm 0.82 \\
\hline 10 & $\mathrm{NO}_{2}$ & \pm 0.73 \\
\hline 11 & $\mathrm{O}_{2}$ & \pm 0.60 \\
\hline 12 & Smoke opacity & \pm 0.62 \\
\hline
\end{tabular}

\section{Results and Discussion}

In this section, the findings of the performance and exhaust emission characteristics for 1-pentanol/diesel binary blends have been presented and compared to a reference with mineral diesel fuel. Further, the aforementioned re- sults have been discussed in the light of the recent literature.

\subsection{Brake specific fuel consumption}

BSFC can be described as the fuel consumption in a mass of the tested engine per unit output power generation. It is to be noted that BSFC is depended on the fuel properties such as density, viscosity, LCV, cetane number [69]. As a result of the tests in the study, the effects of the fuels obtained by adding 1-pentanol in different volumes to standard diesel fuel on BSFC were evaluated. The comparisons of the BSFC outcomes as a function of the load for the tested fuels during the experimental studies were portrayed in Fig. 2. As seen in Fig. 2, BSFC figures for all binary blends have been observed as elevated than that of diesel throughout the entire engine loads. BSFC values for 1-pentanol/diesel fuel blends have been noticed as higher than that of diesel fuel entire the engine loads. At the highest load, BSFC results for diesel, Pt10, Pt20, and Pt30 were calculated to be as $371.14 \mathrm{~g} / \mathrm{kWh}, 390.95 \mathrm{~g} / \mathrm{kWh}, 407.68$ $\mathrm{g} / \mathrm{kWh}$, and $422.83 \mathrm{~g} / \mathrm{kWh}$, respectively The increase in the concentration of 1-pentanol in the binary blend has led to a turn in up BSFC values. This is the fact that the 1-pentanol has a higher LHV value than that of diesel fuel (as observed in Table 4). Namely, the alcohol retracts more heat from the combustion chamber throughout the vaporization stage and hence, it brings about a quenching impact resulting in a decrement of the combustion efficiency. Due to the LCV of 1-pentanol compared to pure diesel (as observed in Table 4), the fuel consumption rises as the ratio of 1pentanol ascends in the blends. As hoped, since the tested engine maintains the same amount of power generation, it consumes more fuel while operating with 1-pentanol/diesel fuel blends owing to the fact that 1-pentanol possesses a lesser heat of combustion. The similar results and their reasons were also found by Refs. [63, 70, 71].

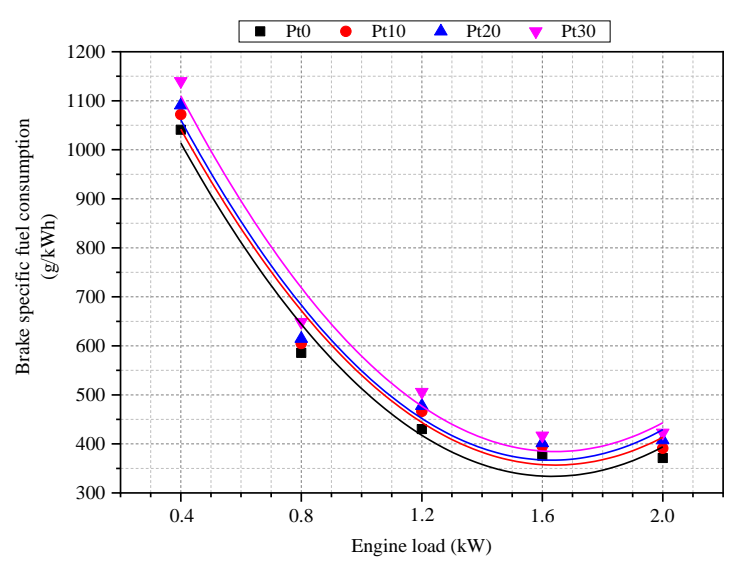

Fig. 2. The variations of BSFC according to different engine loads 


\subsection{Brake specific energy consumption}

BSEC is an important indicator that is used to figure out the amount of energy consumption by the tested engine to the production of unit power. For this reason, it is clearly stated that the BSEC is a more reasonable parameter as compared to BSFC as mentioned above so as to compare any fuels having dissimilar heating values and densities. BSEC can be computed by multiplying the LCV of the tested fuel sample with BSFC result [72]. Fig. 3 illustrates the change in BSEC values on the influences of 1-pentanol infusion into the straight diesel fuel against the engine loads. The increase in the load caused to a mitigation in BSEC values. The possible reason for this case could be clarified that the number of required fuel running on the tested engine per unit output energy under the higher loads reduced [73]. As expected, it can be noticed that pure diesel fuel has the least BSEC values entire loads amongst the fuels by virtue of the LCVs and higher density of the 1pentanol. The average BSEC values for diesel, Pt10, Pt20, and Pt30 were determined to be as $24.21 \mathrm{MJ} / \mathrm{kWh}, 24.88$ $\mathrm{MJ} / \mathrm{kWh}, 25.13 \mathrm{MJ} / \mathrm{kWh}$, and 25.69 MJ/kWh, respectively. Particularly, the infusion of 1-pentanol with diesel fuel caused to increase the BSEC values at all engine loads. As mentioned before, the higher oxygen concentration in the alcohol has led to reduce the calorific value and therefore, the consumption of fuel boosts to generate the identical output of power from the tested engine. Ashok et al. [74] reported that the less calorific value, high boiling point, and viscosity characterization might be a conceivable ground in terms of increasing the BSEC. Babu and Anand [75] observed that the supplementation of n-hexanol or n-pentanol into the diesel/biodiesel fuel blends at ratios of $5 \%$ and $10 \%$ caused to increase BSEC values contrary to the diesel on account of the LCV of the alcohols than those of biodiesel and diesel fuel.

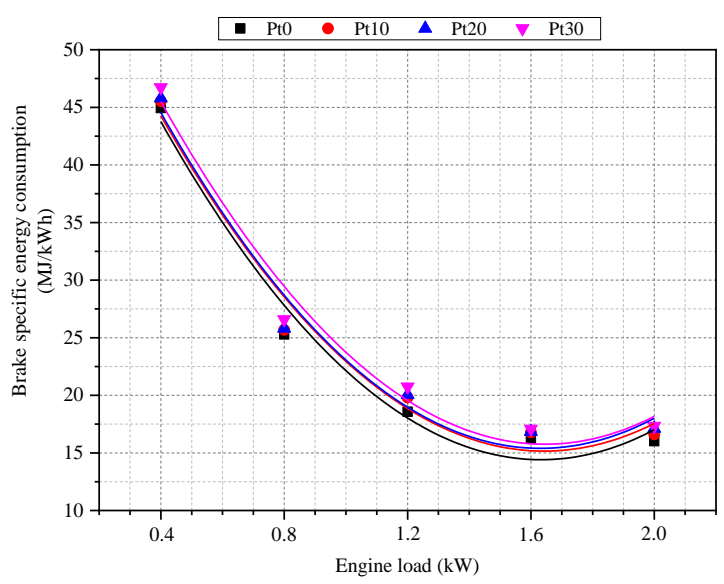

Fig. 3. The variations of BSEC according to different engine loads

\subsection{Brake thermal efficiency}

BTE has been known as an engine efficiency obtained by the rate of output power to input energy amount ensured from the fuel. It seems to be a very important parameter for the engine and generally used to predict how well any engine may transform the heat from any fuel to mechanical energy [72]. By all means, the BTE is the inverse of BSFC and LCV of the tested fuel [69]. BTE of the tested fuels operated in the engine trials was calculated thanks to Eq. (1) and given in Fig. 4 as a function of load. From the graph, BTE figures augmented with regards to the load for all fuel samples. To conclude with, the peak BTE figures were revealed at the highest load condition for all the fuels. At 2 $\mathrm{kW}$, the BTE values of diesel, Pt10, Pt20, and Pt30 were found to be at $22.47 \%, 21.68 \%, 21.03 \%$, and $20.77 \%$, respectively. As the 1-pentanol ratio increases in the fuel blends, the BTE results decreases slightly. The basic reason for this is because LCV of 1-pentanol is lesser than that of pure diesel. Campos-Fernández et al. [52] and Wei et al. [63] stated that there was no change in BTE values against pentanol infusion to the diesel fuel. However, Yilmaz and Atmanli [57] highlighted that the treatment of diesel with pentanol exhibited sharp reductions in BTE values and 5$35 \%$ pentanol addition to diesel fuel exhibited average decrements of $13.85-22.98 \%$ in BTE results in contrast to the baseline diesel. Zhang et al. [76] indicated that a higher LHV of pentanol could decrease the combustion process temperature leading to a decline of the BTE. Kumar and Saravanan [77] observed that the BTE dropped in the engine while the utilization of pentanol/diesel fuel blends.

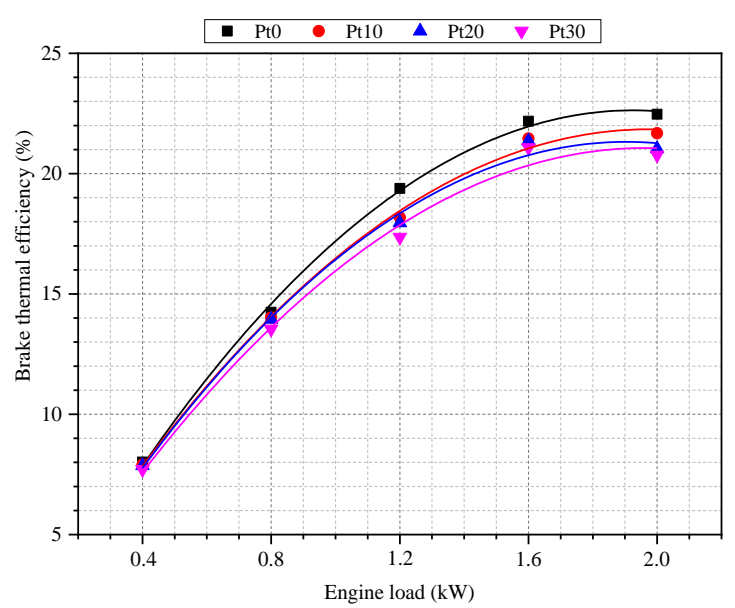

Fig. 4. The variations of BTE according to different engine loads 


\subsection{Exhaust gas temperature}

With the help of an exhaust system in the diesel generator used in experimental studies, the products obtained at the end of the combustion were released into the atmosphere. One of the most remarkable characteristics of an engine that affect exhaust emissions is EGT. EGT results of the fuel samples under diverse loads are exhibited in Fig. 5. The highest EGT figures were obtained for all of the fuels with the raise of engine load. It was noticed that the injected number of fuel into the engine cylinder augments leading to a rise of temperature in the cylinder as the load increases $[48,78]$. The amount of nitrogen oxides $\left(\mathrm{NO}_{\mathrm{X}}\right)$ formed during the combustion process largely depends on the temperature. As a result of dilution of the fresh mixture in the combustion chamber with exhaust gases, the end of combustion temperatures can reduce and hence the amount of $\mathrm{NO}_{\mathrm{X}}$ formation decreases. This subject would be elaborately presented in the related section giving the information regarding the $\mathrm{NO}_{\mathrm{X}}$ formation mechanisms. It can be noted that the operating conditions of the test engine like injection pressure, compression ratio, fuel injection timing, etc. and fuel specifications such as energy content, cetane number, density, viscosity, etc. are mostly indicated as the most significant parameters for varying the EGT [79].

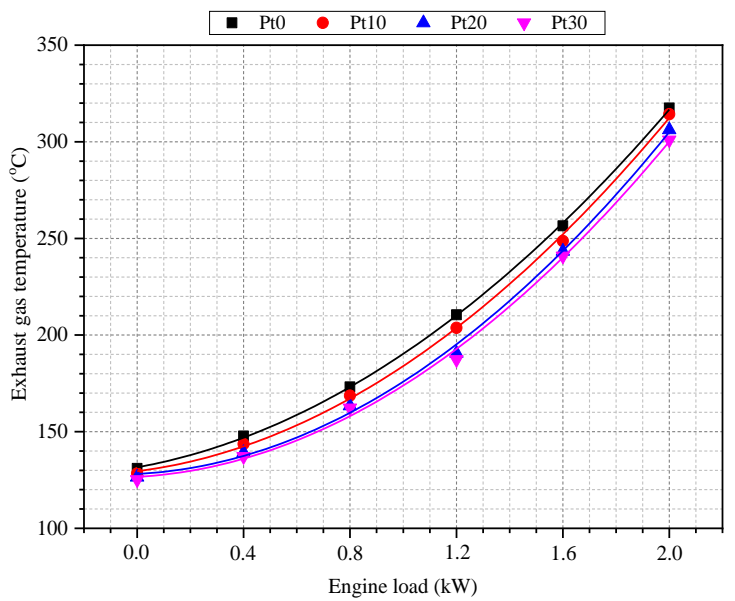

Fig. 5. The variations of EGT values according to different engine loads

With the infusion of alcohol to diesel fuel, EGT values commenced declining slightly in contrast to the diesel fuel. The peak EGT values for Pt10, Pt20, and Pt30 were measured to be as $314.3^{\circ} \mathrm{C}, 306.2^{\circ} \mathrm{C}$, and $300.9^{\circ} \mathrm{C}$, respectively while the maximum EGT for diesel fuel was experienced as $317.5^{\circ} \mathrm{C}$. Due to the higher LHV, there was a reduction in EGT values when the alcohol was added to the diesel fuel. As also mentioned above, the higher LHV can absorb the heat from the combustion chamber resulting in the drop of the end temperature [77]. Another important parameter for observing the reduction in EGT values for 1-pentanol/diesel blends in comparison with the straight diesel fuel is LCV.
As seen in Table 4, the 1-pentanol has lower energy content than that of diesel. Also, diesel fuel has the highest LCV amongst the tested fuel. It caused the production of more heat inside the cylinder and thereby EGT values observed as the maximum for diesel. Similarly, Wei et al. [63] marked that $\mathrm{n}$-pentanol addition into diesel caused slight reductions in EGT values owing to the lower energy content and a higher LHV of the n-pentanol. Furthermore, similar scenarios were explained with the mixtures of diesel fuel with alcohol having various carbon atoms in the literature [80, 81]. Yilmaz and Atmanli [57] exhibited an opposing knowledge that the treatment of pure diesel fuel with higher alcohol (pentanol) led to a reduction in the cetane number owing to the less cetane number of alcohol, resulting in the rise of EGTs. Furthermore, the excessive amount of oxygen molecule found in the alcohol could positively influence the combustion efficiency in the engine and thus in the meantime associate with the raise in the EGT.

\subsection{Carbon dioxide emission}

In recent years, international protocols have been prepared to mitigate the harmful exhaust emissions to the environment from vehicles powered with internal combustion engines. Consequently, harmful pollutants are expected to be lower in the usage of alternative fuels that will become a candidate for petroleum products. $\mathrm{CO}_{2}$ emission changes for the tested fuels obtained in the present experimental studies are demonstrated in Fig. 6. From the graph, $\mathrm{CO}_{2}$ emission is the highest value for all 1-pentanol/diesel fuel blends and neat diesel at the load of $1.2 \mathrm{~kW}$. The peak $\mathrm{CO}_{2}$ emissions for diesel, Pt10, Pt20, and Pt30 were detected to be at $2.31 \%, 2.24 \%, 1.72 \%$, and $1.50 \%$, respectively. When Eqs. (6) and (7) are examined, it has been seen that the carbon atoms in the chamber of the combustion are oxidized with a sufficient amount of oxygen to form the complete combustion product that is $\mathrm{CO}_{2}$ emission, which is known as the responsible for the greenhouse gas resulting in global warming [82]. All the tested fuels exhibited almost similar inclination in the $\mathrm{CO}_{2}$ profile across the load. $\mathrm{CO}_{2}$ generated by biomass-based alternative fuels does not have a negative impact on the environment since the released $\mathrm{CO}_{2}$ gas can be used by plants in the course of the photosynthesis process during growth [83]. This means briefly net-zero carbon emission from the engine if it can operate with the above mentioned clean fuels like pentanol [84]. As reported before, the pentanol can be produced from biomass resources. As seen, the tested engine formed more $\mathrm{CO}_{2}$ emissions for all the engine loads when it was fuelled with diesel fuel. But, $\mathrm{CO}_{2}$ emissions were gradually reduced by adding 1-pentanol into the diesel fuel and thereby the lowest results were appeared with Pt30 blend fuel. It could be noted as the 1-pentanol amount in the blends rose progressively, the generation of $\mathrm{CO}_{2}$ in the exhaust reduced. This case can be explained as the cooling influence of the 1-pentanol leading 
inefficacious oxidation process of carbon monoxide to dioxide inside the cylinder. Also, $\mathrm{CO}_{2}$ formation in the endcombustion products also depends on the $\mathrm{C} / \mathrm{H}$ ratio of fuels. Rising the mass of carbon atoms in the fuel content causes $\mathrm{CO}_{2}$ ratio in the exhaust gas to increase. Nanthagopal et al. [72] observed that the higher-order alcohol addition to the methyl ester obtained from oil of Calophylluminophyllum brought about the declining $\mathrm{CO}_{2}$ emissions according to the pure methyl ester fuel throughout the operation of the tested engine. This is because of higher amounts of oxygen atoms and hydrogen molecules in the chemical structures of the alcohol and hence the generation of $\mathrm{CO}_{2}$ reduced. Akar [85] tested diesel fuel/butanol/false flax biodiesel ternary blends in the CI engine. The researcher accomplished that the higher-order alcohol supplementation into diesel/biodiesel blend resulted in decreasing for the perspective of the $\mathrm{CO}_{2}$ emissions. A similar decrement was also indicated by Alptekin et al. [86] who pointed out that $\mathrm{CO}_{2}$ emission for the $20 \%$ bioethanol $/ 60 \%$ diesel $/ 20 \%$ waste cooking oil biodiesel ternary blends gone down up to $7.1 \%$ when compared to diesel under $600 \mathrm{Nm}$ load because of lesser $\mathrm{C} / \mathrm{H}$ proportion of the bioethanol.

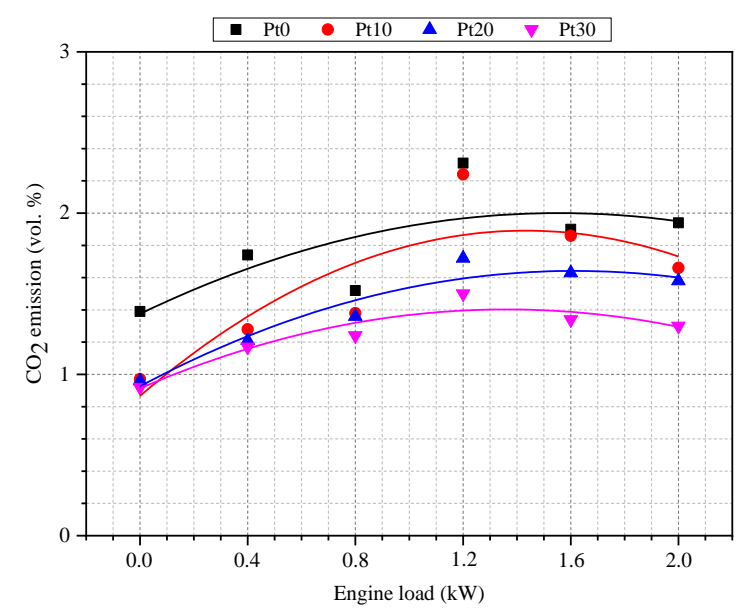

Fig. 6. The variations of $\mathrm{CO}_{2}$ emissions for all tested fuels in different engine loads

\subsection{Carbon monoxide emission}

In cases where the carbon atoms cannot react with a sufficient amount of oxygen during the combustion, $\mathrm{CO}$ is formed that the indicator of the incomplete combustion process in the cylinder. The shortage of oxygen molecule concentration inside the cylinder and excessively lean or rich mixtures causes a higher $\mathrm{CO}$ generation [61]. The influence of pure diesel and 1-pentanol/diesel blends on $\mathrm{CO}$ emissions is presented in Fig. 7. As observed, the larger proportion of alcohol in the fuel blends results in higher $\mathrm{CO}$ emissions throughout all of the engine loads, especially at the higher loads. At $2 \mathrm{~kW}$ engine load, the $\mathrm{CO}$ emissions for diesel fuel, Pt10, Pt20, and Pt30 were found to be at
$0.10 \%, 0.19 \%, 0.45 \%$, and $0.70 \%$, respectively. Although the number of carbon atom in the chemical structure of 1pentanol is less than that of pure diesel, $\mathrm{CO}$ emissions are higher in 1-pentanol/diesel fuel blends. The highest value for the $\mathrm{CO}$ emission was obtained by the Pt30 fuel at all engine load conditions. Accordingly, these findings were compatible with the results of experiments performed by Refs. [63, 87, 88]. Kumar and Saravanan [77] indicated that the higher LHV feature of pentanol led to withdrawn a higher amount of heat from the chamber of combustion, as a result of the quenching impact, leading descend in the combustion efficiency of the tested engine and hence the generation of $\mathrm{CO}$ emission increased. No doubt, the temperature of the intake air sucked to the cylinder could be increased to overcome and mitigate the CO emissions [89]. Yilmaz and Atmanli [57] indicated that the low cetane number for pentanol could be a substantial parameter in the rising of $\mathrm{CO}$ emissions. On the other hand, the researchers presented that the low fraction ( $5 \%$ by volume) of pentanol addition to diesel fuel occurred an opposing trend on the emissions of CO. In other words, $5 \%$ pentanol $+95 \%$ diesel fuel blend ensured a decrement in CO emission by $16.39 \%$ on average when compared to diesel. But, $\mathrm{CO}$ emissions were augmented related to the increase in the concentration (between $10 \%$ and $35 \%$ ) of pentanol in the blend. Nanthagopal et al. [72] pointed out that the higher-order alcohol (1-butanol and 1-pentanol)/biodiesel blends produced more $\mathrm{CO}$ emissions from the exhaust for all loads on account of the higher LHV as well as worse ignition features of the aforementioned long-chain alcohols resulting in the incomplete combustion reaction inside the cylinder and hence higher amount of $\mathrm{CO}$ emissions could be formed. Kumar et al. [90] noticed that the formation of CO gas in the blends of long-chain alcohol with diesel fuel or biodiesel has been heavily dependent on the content of the carbon atoms in the fuel samples. Namely, the rise in the number of carbon atoms would raise $\mathrm{CO}$ emissions owing to the declining in the oxygen fraction.

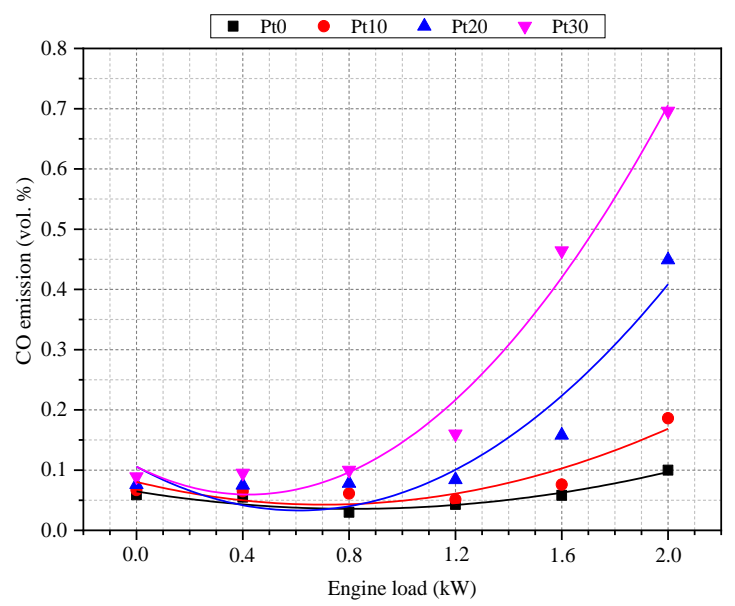

Fig. 7. The variations of $\mathrm{CO}$ emissions for all tested fuels in different engine loads 


\subsection{Unburned hydrocarbon emission}

One of the most significant parameters for observing the quality of the combustion taking place inside the engine cylinder is unburned $\mathrm{HC}$ emissions. HC emissions occur because of not only the uncompleted combustion reaction but also slower oxidation process due to the very rich or poor air/fuel ratios in the combustion chamber, loss of heat to low-temperature zones around the cylinder, and cooling flame in the above-mentioned zones [91, 92]. Fig. 8 portrays the comparison of unburned $\mathrm{HC}$ emissions for the tested fuel samples (diesel and 1-pentanol/diesel blends) across the various engine load conditions. Unburned HC emissions obtained by using 1-pentanol/diesel fuel blends are higher than that of neat diesel as seen in Fig. 8. Besides, the maximum unburned $\mathrm{HC}$ emissions for all tested fuels were appeared under the highest load of $2 \mathrm{~kW}$, and further at this load, the unburned HC emissions for Pt10, Pt20, and Pt30 were obtained to be as 259 ppm, 352 ppm, and 399 ppm, respectively. The unburned HC emission for unmodified diesel fuel was measured to be as $180 \mathrm{ppm}$. This substantial boosting is a good agreement with the raise in $\mathrm{CO}$ emissions, as observed in Fig. 7.

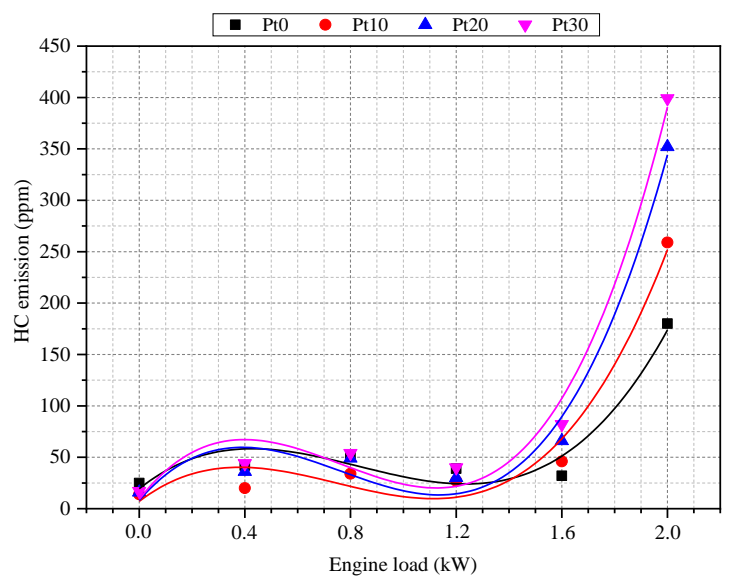

Fig. 8. The variations of $\mathrm{HC}$ emissions for all tested fuels in different engine loads

Increasing the amount of oxygen in 1-pentanol/diesel fuel mixtures affects increasing the combustion rate and temperature. Since the cetane number of 1-pentanol is lesser than that of pure diesel, it causes a prolong of ignition delay duration in the combustion reaction. Incomplete combustion formed due to the sudden combustion reaction of the fuel accumulated in the cylinder and shortening of the combustion period increases $\mathrm{HC}$ emissions [77]. Moreover, the low cetane number characteristic of the fuel is influenced by the specifications of the spray and volatility of the fuel, and low-temperature combustion chemistry as well [93]. Sharon et al. [82] and Kumar et al. [90] pointed out that the higher LHV of the pentanol caused to drop the temperature of the cylinder because of the cooling effects, which result- ed in contributing to the augmentation of the generation of unburned HC emissions. Karabektas and Hosoz [81] observed that the addition of $5-20 \%$ isobutanol to diesel caused an increase in $\mathrm{HC}$ emissions by between 12.9 and $32.9 \%$ as compared to diesel. Yilmaz and Atmanli [57] found that $5 \%, 10 \%, 20 \%, 25 \%$, and $35 \%$ by volume pentanol addition to the diesel fuel revealed increments to be as in the order of $16.63 \%, 45.55 \%, 97.78 \%, 182.10 \%$, and $379.48 \%$ on average. Atmanli and Yilmaz [94] researched the influences of 1-pentanol and n-butanol infusion on the diesel for the emission levels. Based on the measurements, the researchers stated that the tested binary blends occurred a rise of $283.39 \%$ averagely in the unburned $\mathrm{HC}$ emissions. Contrary to the aforementioned outcomes, Altun et al. [95] observed reductions in the $\mathrm{HC}$ emissions with the rise in the higher-alcohol (butanol) concentration in the blend.

\subsection{Nitrogen oxides emissions}

The air consists of $\mathrm{N}_{2}$ at a ratio of approximately $78 \%$ and this gas accepts as the inert gas. In other words, $\mathrm{N}_{2}$ cannot react with the oxygen molecules in normal cases. On the other hand, $\mathrm{N}_{2}$ can react with oxygen molecules associated with the elevated temperature in the combustion chamber. $\mathrm{NO}_{\mathrm{X}}$ are formed by the nitrogen monoxide (NO) and nitrogen dioxide $\left(\mathrm{NO}_{2}\right)$. In the $\mathrm{NO}_{\mathrm{X}}$, a higher amount of $\mathrm{NO}$ gas (approximately $90 \%$ by volume) and a lesser amount of $\mathrm{NO}_{2}$ gas (approximately $5 \%$ by volume) are found in general [57]. Moreover, the other oxides of nitrogen $\left(\mathrm{NO}_{3}\right.$, $\mathrm{N}_{2} \mathrm{O}_{5}, \mathrm{~N}_{2} \mathrm{O}$, etc.) are not considered while determining the $\mathrm{NO}_{\mathrm{X}}$ emissions. Nitrogen oxides $\left(\mathrm{NO}_{\mathrm{X}}\right)$ emissions occur in the cylinder due to reasons such as high pressure, temperature, and excess oxygen quantity during the combustion process in the engine [96]. The understanding of the formation mechanisms for the $\mathrm{NO}_{\mathrm{X}}$ emissions can be mentioned as a significant subject in the emission analysis in the point of the mitigating of the $\mathrm{NO}_{\mathrm{X}}$ emission emitting from the CI engines. Zeldovich or thermal, Fenimore or prompt, the $\mathrm{NNH}$, fuel-bound nitrogen, and $\mathrm{N}_{2} \mathrm{O}$ pathway have been known as the most widespread $\mathrm{NO}_{\mathrm{X}}$ formation mechanisms used in the literature [97]. However, the $\mathrm{NO}_{\mathrm{X}}$ formation mechanism in the $\mathrm{CI}$ engines is commonly identified by the Zeldovich mechanism from the availability of nitrogen, oxygen, and hydrogen free radicals. The general equations of the aforementioned mechanism are represented underneath [98].

$$
\begin{aligned}
N_{2}+[O] & \leftrightarrow O+[N] \\
{[N]+O_{2} } & \leftrightarrow N O+[O] \\
{[N]+O H } & \leftrightarrow N O+[H]
\end{aligned}
$$

Fig. 9 shows the alteration of the $\mathrm{NO}_{\mathrm{X}}$ emission figures for all the tested fuel samples under various loads. The av- 
erage $\mathrm{NO}_{\mathrm{x}}$ emissions for diesel, Pt10, Pt20, and Pt30 were determined to be as $165.80 \mathrm{ppm}, 143.53 \mathrm{ppm}, 115.76 \mathrm{ppm}$, and $96.82 \mathrm{ppm}$, respectively. As observed, the $\mathrm{NO}_{\mathrm{X}}$ emission values of the different blends in the diesel engine generator used in the study decreased depending on the increase in the amount of 1-pentanol. LCV and higher LHV of the 1-pentanol compared to that of pure diesel fuel led to decrease the occurrence of the $\mathrm{NO}_{\mathrm{x}}$ emission. Since the air/fuel ratio in the cylinder will increase with the increase in load, the gas temperature increases in the combustion chamber. In other words, the utilization of pentanol in the diesel fuel as an oxygenated alternative fuel additive reduces the temperature of the engine cylinder throughout the combustion process by causing the leaner air/fuel mixture and hence decreases the $\mathrm{NO}_{\mathrm{X}}$ emissions [20]. The lowest value for the $\mathrm{NO}_{\mathrm{x}}$ emission was obtained by the Pt30 blend fuel all of the engine load conditions. EGT increase with the increase of load, $\mathrm{NO}_{\mathrm{x}}$ emission values were increased in all fuel blends as seen in Figs. 5 and 9. The main reason for this is the decreased rate of heat transfer through the coolant in the cylinder wall. Mahalingam et al. [99] found that the adding $10 \%$ and $20 \%$ by volume pentanol to mahua oil biodiesel caused to $3.3 \%$ and $3.9 \%$ mitigation in the emissions of $\mathrm{NO}_{\mathrm{X}}$, respectively. The $\mathrm{NO}_{\mathrm{X}}$ emission forms during the combustion of diesel fuel and is the most important contaminant component that must be controlled. Devarajan et al. [47] stated that the $\mathrm{NO}_{\mathrm{X}}$ emissions could be pushed down by decreasing the combustion temperature. However, the researchers observed that the addition of pentanol to cashew nut shell biodiesel resulted in higher $\mathrm{NO}_{\mathrm{X}}$ emissions than that of diesel entire brake power conditions because of the inherent oxygen content in the biofuels leading to encourage the combustion and therefore turn in up the temperature inside the cylinder. Shu et al. [100] suggested that the pilot injection postponing might be a powerful technique so as to drop the $\mathrm{NO}_{\mathrm{X}}$ formation of a $\mathrm{CI}$ engine fuelled with the natural gas/diesel blend.

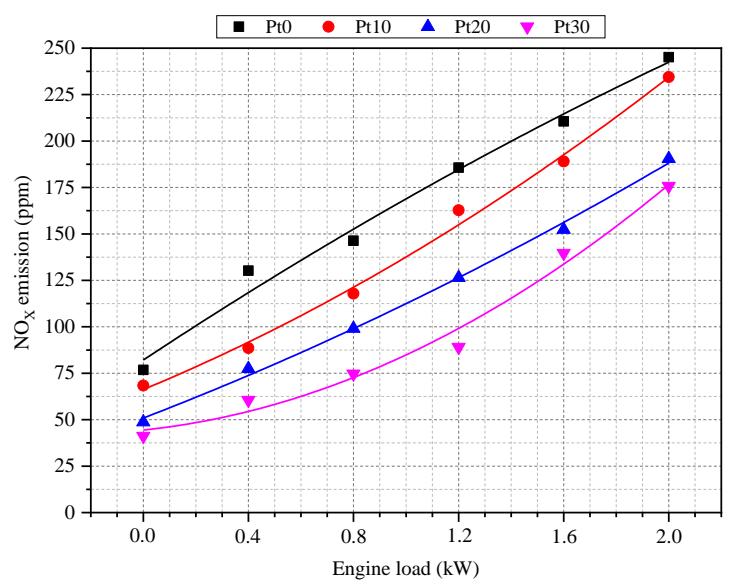

Fig. 9. The variations of $\mathrm{NO}_{\mathrm{x}}$ emissions for all tested fuels in

different engine loads

\subsection{Oxygen emission}

One of the most substantial factors ensuring the complete combustion in the combustion chamber is the proportion of the oxygen atoms in the cylinder. During the combustion process, the carbon atoms in the fuel chemical structure react with the oxygen atoms in the air. As a result of the utilization of alcohol-based fuels with oxygen atoms in its chemical structure, the oxygen emission during combustion increases in diesel engines. Oxygen emission emitted from the tested engine changes obtained in experimental studies is given in Fig. 10. The oxygen emission of 1pentanol/diesel fuel blends is higher than that of pure diesel because of the inherent oxygen content of 1-pentanol. The average oxygen emission for the diesel fuel, Pt10, Pt20, and Pt30 were found to be at $18.21 \%, 18.57 \%, 19.04 \%$, and $19.23 \%$, respectively. To the best of the authors' knowledge, a limited number of researcher studied the oxygen emissions during the engine tests. Aydın and Ogut [38], for instance, investigated the oxygen emissions of the test engine fuelled with bioethanol/biodiesel/diesel fuel blends. The researchers noticed that the addition of bioethanol caused to increase the oxygen emissions in comparison with traditional diesel fuel because of the excessive amount of oxygen molecules in the bioethanol. Yesilyurt et al. [101] have observed that the infusion of long-chain alcohols like 1butanol and n-pentanol to the yellow mustard oil biodiesel/diesel fuel blends at ratios of 5 and $10 \%$ on a volume basis resulted in turn up the oxygen emissions by averagely $84.62-121.34 \%$ for 1-butanol added fuel blends, and 52.74$78.38 \%$ for n-pentanol treated alternativefuel blends in comparison with the conventional diesel.

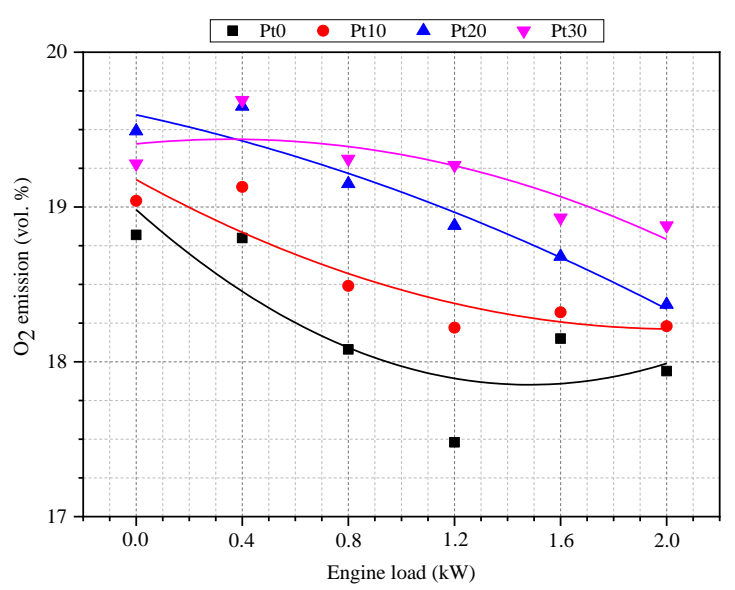

Fig. 10. The variations of oxygen emissions for all tested fuels in different engine loads 


\subsection{Smoke opacity}

Fig. 11 portrays the alteration of smoke emissions for Pt10, Pt20, Pt30, and mineral diesel fuel against engine load between no load to $2 \mathrm{~kW}$. As seen, the smoke emissions increase in most case with load for all tested fuel samples. This is due to the fact that a supplemental amount of fuel can be required with the identical number of air in the combustion chamber where makes the air/fuel ratios as a rich and leads to becoming incomplete combustion process and thereby higher smoke emissions in the exhaust [102]. The unmodified diesel fuel formed more smoke than that of the binary blends of 1-pentanol and diesel fuel. This can be mainly explained as the atomization stages of air has been enhanced by using the oxygenated fuel additives. At the highest load, smoke emissions for diesel, Pt10, Pt20, and Pt30 were noted to be at $59.78 \%, 13.16 \%, 8.54 \%$, and $7.14 \%$, respectively. Another reason for improvement of the smoke emissions by the utilization of 1-pentanol can be mentioned by the intensification of oxygen molecule fraction due to the alcohol [103]. Rakopoulos et al. [104] researched the influences of butanol/diesel blends on the exhaust gas emissions of a DI diesel engine under various loads and they reported that the smoke emissions were drastically decreased with the addition of butanol to diesel fuel. Emiroğlu and Şen [105] indicated that the use of alcohol in the diesel fuel decreased in the smoke emission levels due to the higher content of the oxygen and lesser $\mathrm{C} / \mathrm{H}$ of the alcohol-based alternative fuels. With the above-mentioned perspective, the 1-pentanol has $4.999 \mathrm{C} / \mathrm{H}$ ratio while diesel fuel has 6.722 in the present study, as tabulated in Table 4. Therefore, the 1-pentanol addition to diesel fuel caused to drop the smoke emission grades in the exhaust gas. Moreover, these findings are also similar to other investigations conducted by Refs [28, 106, 107].

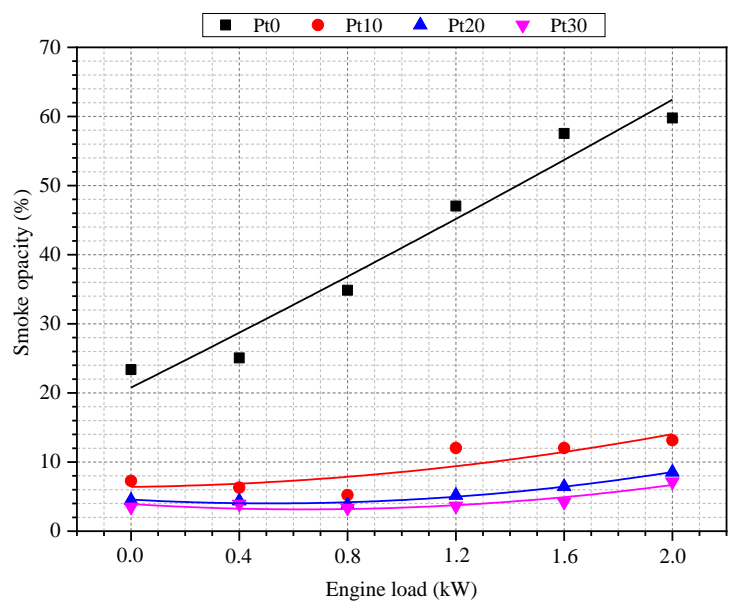

Fig. 11. The variations of smoke emissions for all tested fuels in different engine loads

\section{Conclusions}

In the present experimental study, the effects of different 1-pentanol/diesel fuel blends (Pt10, Pt20, and Pt30) on the engine performance and exhaust emission characteristics have been researched at a constant engine speed of 3000 rpm for six different engine loads (from no load to $2 \mathrm{~kW}$ intervals of $0.4 \mathrm{~kW}$ ) in a single-cylinder, four-stroke, naturally-aspirated, DI diesel engine and the outcomes have been compared with the conventional diesel fuel. Based on the engine test of the aforementioned fuel samples, the following conclusions have been drawn from this work.

1. The most significant benefit of 1-pentanol/diesel fuel blends is to be noted that this higher-order alcohol could be successfully and safely performed in a CI engine coupled with a generator out of any modification on the tested engine along without any extra additive.

2. The 1-pentanol infusion with straight diesel fuel caused to decline of the energy content along with the cetane number of the tested fuel samples. Accordingly, Pt30 showed the lowest cetane number and calorific value amongst the tested fuels. The higher content of oxygen in the 1-pentanol leads to decrease the energy content. With this, in comparison to pure diesel fuel under the same experimental conditions, it has been observed that the BSFC and BSEC values increased as the amount of 1-pentanol increased in the blends. The order from least to utmost was as follows: diesel fuel < Pt10 < Pt20 < Pt30.

3. The being of $10 \%, 20 \%$, and $30 \%$ by volume $1-$ pentanol in the fuel blends has turned down the EGT values when compared to the unmodified diesel fuel. The EGT values of Pt10, Pt20, and Pt30 blends were found to be lower than the of diesel by $2.35 \%, 5.44 \%$, and $6.9 \%$ on average, respectively, which can be attributed to the higher LHV feature of the 1-pentanol than that of diesel fuel.

4. 1-pentanol/diesel fuel blends generated a higher amount of $\mathrm{CO}$ emission than diesel fuel owing to the higher LHV of used alcohol. In addition, the use of the above mentioned alternative fuel blends in the tested engine led to reducing the formation of $\mathrm{CO}_{2}$ emission in the exhaust. It is clear that the formation of $\mathrm{CO}_{2}$ gas from the burning of biomass-based fuel candidates has negligible because the emitting $\mathrm{CO}_{2}$ can be absorbed by plants throughout the process of photosynthesis.

5. The utilization of 1-pentanol with diesel fuel at various ratios augmented the unburned HC emissions as compared to the diesel fuel, which gener- 
ated the lowest $\mathrm{HC}$ emission, because of the poor self-ignition characterizations of the tested fuel blends owing to lesser cetane number resulting in the cooling effect in the combustion chamber, especially leaner mixture regions inside the cylinder.

6. The usage of 1-pentanol with diesel fuel caused to release more oxygen emission from the exhaust because of the inherent oxygen content of the alcohol. The oxygen emission levels for the tested fuels were observed to be between $18.21 \%$ and $19.23 \%$.

7. The existence of $10 \%, 20 \%$, and $30 \%$ on a volume basis 1-pentanol in the blends reduced $\mathrm{NO}_{\mathrm{X}}$ emissions in comparison with diesel by $13.43 \%$, $30.18 \%$, and $41.61 \%$, respectively.

8. The addition of 1-pentanol to diesel fuel was appeared that it provided a noticeable reduction in the smoke opacity. The smoke emissions for diesel fuel, Pt10, Pt20, and Pt30 were measured to be as $59.78 \%, 13.16 \%, 8.54 \%$, and $7.14 \%$, respectively at the highest load.

Overall, it can be stated that the binary blends of 1pentanol, which is an important higher-order alcohol, with diesel would be a possible and feasible substitute for baseline diesel fuel in the points of the short-term practices in a diesel engine. On the other hand, prior to intend for using the aforementioned blends as an alternative fuel candidate for the CI engine applications, plenty of systematical investigation has to be performed in the long-term durability and reliability aspects. By all means, there is a necessary for a lot of innovative procedures in order to obtain the longchain alcohols from renewable and sustainable resources.

\begin{tabular}{|c|c|c|}
\hline \multicolumn{3}{|c|}{ Nomenclature } \\
\hline $\mathrm{C}_{14} \mathrm{H}_{25}$ & $:$ & Diesel fuel \\
\hline $\mathrm{C}_{5} \mathrm{H}_{12} \mathrm{O}$ & $:$ & Pentanol \\
\hline$C I$ & $:$ & Compression-ignition \\
\hline $\mathrm{CO}_{2}$ & $:$ & Carbon dioxide \\
\hline $\mathrm{CO}$ & $:$ & Carbon monoxide \\
\hline$D I$ & $:$ & Direct-injection \\
\hline $\mathrm{SO}_{2}$ & $:$ & Sulfur dioxide \\
\hline$H C$ & $:$ & Hydrocarbon \\
\hline$L P G$ & $:$ & Liquefied petroleum gas \\
\hline$C N G$ & $:$ & Compressed natural gas \\
\hline$N O_{X}$ & $:$ & Nitrogen oxides \\
\hline NO & $:$ & Nitrogen monoxide \\
\hline
\end{tabular}

\begin{tabular}{|c|c|c|}
\hline $\mathrm{NO}_{2}$ & : & Nitrogen dioxide \\
\hline $\mathrm{O}_{2}$ & : & Oxygen \\
\hline OAPEC & : & $\begin{array}{l}\text { Organization of Arab Petroleum Exporting } \\
\text { Countries }\end{array}$ \\
\hline PtO & : & $100 \%$ diesel fuel \\
\hline Pt10 & : & $10 \%$ 1-pentanol $+90 \%$ diesel fuel \\
\hline Pt20 & : & $20 \%$ 1-pentanol $+80 \%$ diesel fuel \\
\hline Pt30 & : & $30 \%$ 1-pentanol $+70 \%$ diesel fuel \\
\hline$B T E$ & : & Brake thermal efficiency \\
\hline$B S F C$ & : & Brake specific fuel consumption \\
\hline$B S E C$ & : & Brake specific energy consumption \\
\hline$I M E P$ & : & Indicated mean effective pressure \\
\hline$I D I$ & : & Indirect-injection \\
\hline$B P$ & : & Brake power \\
\hline$E G T$ & : & Exhaust gas temperature \\
\hline$L H V$ & : & Latent heat of vaporization \\
\hline$\dot{m}_{f}$ & : & Mass flow rate of the fuel \\
\hline$L C V_{f}$ & : & Lower heating value of the fuel \\
\hline$x$ & $:$ & Concentration of the component \\
\hline$y$ & $:$ & Esteemed property \\
\hline$\eta$ & : & Kinematic viscosity \\
\hline$\varphi$ & $:$ & Corresponding property \\
\hline$x_{1}, x_{2}, \ldots, x_{n}$ & : & Independent variables \\
\hline$w_{1}, w_{2}, \ldots, w_{n}$ & $:$ & Uncertainties of independent variables \\
\hline$w_{R}$ & $:$ & Uncertainty of the results \\
\hline$R$ & : & Function of the independent variables \\
\hline
\end{tabular}

References

[1] Dudley, B. (2018). BP statistical review of world energy. BP Statistical Review, London, UK, accessed Aug,6

[2] Afum, B. O., Caverson, D., and Ben-Awuah, E. (2019).A conceptual framework for characterizing mineralized waste rocks as future resource. International Journal of Mining Science and Technology, 29(3), 429-435.

[3] Keith, D. R., Struben, J. J., and Naumov, S. (2020). The diffusion of alternative fuel vehicles: A generalized model and future research Agenda. Journal of Simulation, 118.

[4] Shwadran, B. (2018). Middle East oil crises since 1973. 1st Edition, Routledge, Taylor and Francis Group, ISBN 9780367005962 
[5] Doğan, B., and Erol, D. (2019). The future of fossil and alternative fuels used in automotive industry. (ISMSIT) 3rd International Symposium on Multidisciplinary Studies and Innovative Technologies, IEEE, 1-8.

[6] Abas, N., Kalair, A., and Khan, N. (2015). Review of fossil fuels and future energy technologies. Futures, 69 , 31-49.

[7] Ali, M. B., Saidur, R., and Hossain, M. S. (2011). A review on emission analysis in cement industries. Renewable and Sustainable Energy Reviews, 15(5), 2252-2261.

[8] Carraretto, C., Macor, A., Mirandola, A., Stoppato, A., and Tonon, S. (2004). Biodiesel as alternative fuel: Experimental analysis and energetic evaluations. Energy, 29(12-15), 2195-2211.

[9] Covert, T., Greenstone, M., and Knittel, C. R. (2016). Will we ever stop using fossil fuels? Journal of Economic Perspectives, 30(1), 117-138.

[10] Bae, C., and Kim, J. (2017). Alternative fuels for internal combustion engines. Proceedings of the Combustion Institute, 36(3), 3389-3413.

[11] Awad, O. I., Mamat, R., Ali, O. M., Sidik, N. A. C., Yusaf, T., Kadirgama, K., and Kettner, M. (2018). Alcohol and ether as alternative fuels in spark ignition engine: A review. Renewable and Sustainable Energy Reviews, 82(3), 2586-2605.

[12] Denton, T. (2018). Alternative fuel vehicles. 1st Edition, Routledge, Taylor and Francis Group, ISBN 9781138201316

[13] Carvalho, H. (2016). The end of diesel-powered cars? The Lancet Respiratory Medicine, 4(1), e2-e3.

[14] Carvalho, H. (2019). Air pollution-related deaths in Europe-time for action. Journal of Global Health, 9(2): 020308.

[15] Martins, F., Felgueiras, C., and Smitková, M. (2018). Fossil fuel energy consumption in European countries. Energy Procedia, 153, 107-111.

[16] Dey, S., Caulfield, B., and Ghosh, B. (2018). Potential health and economic benefits of banning diesel traffic in Dublin, Ireland. Journal of Transport and Health, 10, 156-166.

[17] Suryawanshi, S., and Yarasu, R. (2019). Effect of angle variation in $\mathrm{Y}$ shape producer gas carburetor on performance and emission characteristics of a dual fuel CI engine. (ICTEA) 12.International Conference on Thermal Engineering: Theory and Applications, Gandhinagar, India, February 23-26, 1-7.

[18] He, B. Q., Shuai, S. J., Wang, J. X., and He, H. (2003). The effect of ethanol blended diesel fuels on emissions from a diesel engine. Atmospheric Environment, 37(35), 4965-4971.

[19] Tan, P. Q., Hu, Z. Y., Lou, D. M., and Li, Z. J. (2012). Exhaust emissions from a light-duty diesel engine with Jatropha biodiesel fuel. Energy, 39(1), 356-362.

[20] Joy, N., Devarajan, Y., Nagappan, B., and Anderson, A. (2018). Exhaust emission study on neat biodiesel and al- cohol blends fueled diesel engine. Energy Sources, Part A: Recovery, Utilization, and Environmental Effects, 40(1), 115-119.

[21] Arun, N., and Dalai, A. K. (2020). Environmental and socioeconomic impact assessment of biofuels from lignocellulosic biomass. Lignocellulosic Biomass to Liquid Biofuels, ISBN 9780128159361

[22] Singh, D., Sharma, D., Soni, S. L., Sharma, S., and Kumari, D. (2019). Chemical compositions, properties, and standards for different generation biodiesels: A review. Fuel, 253, 60-71.

[23] Firoz, S. (2017). A review: advantages and disadvantages of biodiesel. International Research Journal of Engineering and Technology, 4(11), 530-533.

[24] Pham, M. T., Hoang, A. T., Le, A. T., Al-Tawaha, A. R. M. S., Dong, V. H., and Le, V. V. (2018). Measurement and prediction of the density and viscosity of biodiesel blends. International Journal of Technology, 9(5), 10151026.

[25] Bukkarapu, K. R. (2019). Comparative study of different biodiesel-diesel blends. International Journal of Ambient Energy, 40(3), 295-303.

[26] Suhaimi, H., Adam, A., Mrwan, A. G., Abdullah, Z., Othman, M. F., Kamaruzzaman, M. K., and Hagos, F. Y. (2018). Analysis of combustion characteristics, engine performances and emissions of long-chain alcohol-diesel fuel blends. Fuel, 220, 682-691.

[27] Shamun, S., Garcia, P., and Svensson, E. (2019). Alternative fuels for particulate control in CI engines. Engine Exhaust Particulates. Energy, Environment, and Sustainability. Springer, Singapore, ISBN 9789811332999

[28] Can, Ö., Çelikten, İ., and Usta, N. (2004). Effects of ethanol addition on performance and emissions of a turbocharged indirect injection diesel engine running at different injection pressures. Energy Conversion and Management, 45(15-16), 2429-2440.

[29] Özgür, T., Tosun, E., Özgür, C., Tüccar, G., and Aydın, K. (2017). Performance, emission and efficiency analysis of a diesel engine operated with diesel and diesel-ethanol (e20) blend. International Journal of Science and Technology, 3(3), 51-61.

[30] Khoobbakht, G., Akram, A., Karimi, M., and Najafi, G. (2016). Exergy and energy analysis of combustion of blended levels of biodiesel, ethanol and diesel fuel in a DI diesel engine. Applied Thermal Engineering, 99, 720729.

[31] Chen, H., Su, X., He, J., and Xie, B. (2019). Investigation on combustion and emission characteristics of a common rail diesel engine fueled with diesel/n-pentanol/methanol blends. Energy, 167, 297-311.

[32] Duraisamy, G., Rangasamy, M., and Govindan, N. (2020). A comparative study on methanol/diesel and methanol/PODE dual fuel RCCI combustion in an automotive diesel engine. Renewable Energy, 145, 542-556. 
[33] Pedrozo, V., Lanzanova, T., May, I., Guan, W. and Zhao, H. (2020). The effective use of ethanol for greenhouse gas emissions reduction in a diesel engine. SAE Technical Paper (No. 2019-36-0157).

[34] Al-Esawi, N., Al Qubeissi, M., and Kolodnytska, R. (2019). The impact of biodiesel fuel on ethanol/diesel blends. Energies, 12(9), 1804.

[35] Wyman, C. E. (2018). Ethanol production from lignocellulosic biomass: overview. Handbook on bioethanol: production and utilization, Routledge, Taylor and Francis Group, ISBN 1560325534

[36] Li, Y., Gong, J., Deng, Y., Yuan, W., Fu, J., and Zhang, B. (2017). Experimental comparative study on combustion, performance and emissions characteristics of methanol, ethanol and butanol in a spark ignition engine. Applied Thermal Engineering, 115, 53-63.

[37] Khoobbakht, G., Karimi, M., and Kheiralipour, K. (2019). Effects of biodiesel-ethanol-diesel blends on the performance indicators of a diesel engine: A study by response surface modeling. Applied Thermal Engineering, 148, 1385-1394.

[38] Aydın, F., and Ögüt, H. (2017). Effects of using ethanolbiodiesel-diesel fuel in single cylinder diesel engine to engine performance and emissions. Renewable energy, 103, 688-694.

[39] Kumar, B. R., and Saravanan, S. (2016). Use of higher alcohol biofuels in diesel engines: A review. Renewable and Sustainable Energy Reviews, 60, 84-115.

[40] Peralta- Yahya, P. P., and Keasling, J. D. (2010). Advanced biofuel production in microbes. Biotechnology Journal, 5(2), 147-162.

[41] Yang, Y., Dec, J., Dronniou, N., and Simmons, B. (2010). Characteristics of isopentanol as a fuel for HCCI engines. SAE International Journal of Fuels and Lubricants, 3(2), 725-741.

[42] Dayma, G., Togbé, C., and Dagaut, P. (2011). Experimental and detailed kinetic modeling study of isoamyl alcohol (isopentanol) oxidation in a jet-stirred reactor at elevated pressure. Energy and fuels, 25(11), 4986-4998.

[43] Nour, M., Attia, A. M. A., and Nada, S. A. (2019). Combustion, performance and emission analysis of diesel engine fuelled by higher alcohols (butanol, octanol and heptanol)/diesel blends. Energy Conversion and Management, 185, 313-329.

[44] EL-Seesy, A. I., Kayatas, Z., Hawi, M., Kosaka, H., and He, Z. (2020). Combustion and emission characteristics of a rapid compression-expansion machine operated with N-heptanol-methyl oleate biodiesel blends. Renewable Energy, 147, 2064-2076.

[45] EL-Seesy, A. I., Kosaka, H., Hassan, H., and Sato, S. (2019). Combustion and emission characteristics of a common rail diesel engine and RCEM fueled by $\mathrm{n}$ heptanol-diesel blends and carbon nanomaterial additives. Energy Conversion and Management, 196, 370394.
[46] Radhakrishnan, S., Devarajan, Y., Mahalingam, A., and Nagappan, B. (2017). Emissions analysis on diesel engine fueled with palm oil biodiesel and pentanol blends. Journal of Oil Palm Research, 29(3), 380-386.

[47] Devarajan, Y., babuMunuswamy, D., and Nagappan, B. (2017). Emissions analysis on diesel engine fuelled with cashew nut shell biodiesel and pentanol blends. Environmental Science and Pollution Research, 24, 1313613141.

[48] Babu, M. V., Murthy, M. K. and Rao A. P. G. (2017). Butanol and pentanol: The promising biofuels for CI engines-A review. Renewable and Sustainable Energy Reviews, 78, 1068-1088.

[49] Devarajan, Y., Nagappan, B. K., and Munuswamy, D. B. (2017). Performance and emissions analysis on diesel engine fuelled with cashew nut shell biodiesel and pentanol blends. Korean Journal of Chemical Engineering, 34(4), 1021-1026.

[50] Ma, Y., Huang, S., Huang, R., Zhang, Y., and Xu, S. (2017). Ignition and combustion characteristics of $n$ pentanol-diesel blends in a constant volume chamber. Applied Energy, 185, 519-530.

[51] Ağbulut, Ü., Sarıdemir, S., and Karagöz, M. (2020). Experimental investigation of fusel oil (isoamyl alcohol) and diesel blends in a CI engine. Fuel, 267, 117042.

[52] Campos-Fernández, J., Arnal, J. M., Gomez, J., Lacalle, N., and Dorado, M. P. (2013). Performance tests of a diesel engine fueled with pentanol/diesel fuel blends. Fuel, 107, 866-872.

[53] Santhosh, K., Kumar, G. N., and Sanjay, P. V. (2020). Experimental analysis of performance and emission characteristics of CRDI diesel engine fueled with 1pentanol/diesel blends with EGR technique. Fuel, 267, 117187.

[54] Ashok, B., Jeevanantham, A. K., Nanthagopal, K., Saravanan, B., Kumar, M. S., Johny, A., Mohan, A., Kaisan, M.U., and Abubakar, S. (2019). An experimental analysis on the effect of n-pentanol-calophylluminophyllum biodiesel binary blends in CI engine characteristcis. Energy, 173, 290-305.

[55] Sridhar, R., Jeevahan, J., and Chandrasekaran, M. (2020). Effect of the addition of 1-pentanol on engine performance and emission characteristics of diesel and biodiesel fuelled single cylinder diesel engine. International Journal of Ambient Energy, 41(1), 58-63.

[56] Appavu, P., Madhavan, V. R., Venu, H., and Jayaraman, J. (2019). A novel alternative fuel mixture (dieselbiodiesel-pentanol) for the existing unmodified direct injection diesel engine: performance and emission characteristics. Transactions of the Canadian Society for Mechanical Engineering, 1-9.

[57] Yilmaz, N., and Atmanli, A. (2017). Experimental evaluation of a diesel engine running on the blends of diesel and pentanol as a next generation higher alcohol. Fuel, 210, 75-82. 
[58] Qi, D. H., Geng, L. M., Chen, H., Bian, Y. Z., Liu, J., and Ren, X. C. (2009). Combustion and performance evaluation of a diesel engine fueled with biodiesel produced from soybean crude oil. Renewable Energy, 34(12), 2706-2713.

[59] Özcan, H., and Çakmak, A. Comparative exergy analysis of oxygenated fuel additives in a spark-ignition (SI) engine. International Journal of Automotive Engineering and Technologies, 7(3):124-133.

[60] Lin, J., Gaustad, G., and Trabold, T. A. (2013). Profit and policy implications of producing biodiesel-ethanoldiesel fuel blends to specification. Applied Energy, 104, 936-944.

[61] Atmanli, A., Ileri, E., Yuksel, B., and Yilmaz, N. (2015). Extensive analyses of diesel-vegetable oil-n-butanol ternary blends in a diesel engine. Applied Energy, 145, 155162.

[62] Kashinath, S. A. A., Manan, Z. A., Hashim, H., and Alwi, S. R. W. (2012). Design of green diesel from biofuels using computer aided technique. Computers and Chemical Engineering, 41, 88-92.

[63] Wei, L., Cheung, C. S., and Huang, Z. (2014). Effect of $n$-pentanol addition on the combustion, performance and emission characteristics of a direct-injection diesel engine. Energy, 70, 172-180.

[64] Sarathy, S. M., Park, S., Weber, B. W., Wang, W., Veloo, P. S., Davis, A. C., Togbe, C., Westbrook, C. K., Park, O., Dayma, G., Luo, Z., Oehlschlaeger, M. A., Egolfopoulos, F. N., Lu, T., Pitz, W. J., Sung, C. J. and Dagaut, P. (2013). A comprehensive experimental and modeling study of iso-pentanol combustion. Combustion and Flame, 160(12), 2712-2728.

[65] Tsujimura, T., Pitz, W. J., Yang, Y., and Dec, J. E. (2011). Detailed kinetic modeling of HCCI combustion with isopentanol. SAE International Journal of Fuels and Lubricants, 4(2), 257-270.

[66] Rajak, U., and Verma, T. N. (2018). Effect of emission from ethylic biodiesel of edible and non-edible vegetable oil, animal fats, waste oil and alcohol in CI engine. Energy Conversion and Management, 166, 704718.

[67] Singh, T. S., and Verma, T. N. (2019). Taguchi design approach for extraction of methyl ester from waste cooking oil using synthesized $\mathrm{CaO}$ as heterogeneous catalyst: Response surface methodology optimization. Energy Conversion and Management, 182, 383-397.

[68] Rajak, U., Nashine, P., Singh, T. S., and Verma, T. N. (2018). Numerical investigation of performance, combustion and emission characteristics of various biofuels. Energy Conversion and Management, 156, 235-252.

[69] Atmanl1, A., Yüksel, B., and İleri, E. (2013). Experimental investigation of the effect of diesel-cotton oil-nbutanol ternary blends on phase stability, engine performance and exhaust emission parameters in a diesel engine. Fuel, 109, 503-511.
[70] Campos-Fernández, J., Arnal, J. M., Gómez, J., and Dorado, M. P. (2012). A comparison of performance of higher alcohols/diesel fuel blends in a diesel engine. Applied Energy, 95, 267-275.

[71] Yilmaz, N., Atmanli, A., and Trujillo, M. (2017). Influence of 1-pentanol additive on the performance of a diesel engine fueled with waste oil methyl ester and diesel fuel. Fuel, 207, 461-469.

[72] Nanthagopal, K., Ashok, B., Saravanan, B., Patel, D., Sudarshan, B., and Ramasamy, R. A. (2018). An assessment on the effects of 1-pentanol and 1-butanol as additives with CalophyllumInophyllum biodiesel. Energy Conversion and Management, 158, 70-80.

[73] Lujaji, F., Kristóf, L., Bereczky, A., and Mbarawa, M. (2011). Experimental investigation of fuel properties, engine performance, combustion and emissions of blends containing croton oil, butanol, and diesel on a CI engine. Fuel, 90(2), 505-510.

[74] Ashok, B., Nanthagopal, K., and Vignesh, D. S. (2018). Calophylluminophyllum methyl ester biodiesel blend as an alternate fuel for diesel engine applications. Alexandria Engineering Journal, 57(3), 1239-1247.

[75] Babu, D., and Anand, R. (2017). Effect of biodieseldiesel-n-pentanol and biodiesel-diesel-n-hexanol blends on diesel engine emission and combustion characteristics. Energy, 133, 761-776.

[76] Zhang, Z. H., Chua, S. M., and Balasubramanian, R. (2016). Comparative evaluation of the effect of butanoldiesel and pentanol-diesel blends on carbonaceous particulate composition and particle number emissions from a diesel engine. Fuel, 176, 40-47.

[77] Kumar, B.R., and Saravanan, S. (2015). Effect of exhaust gas recirculation (EGR) on performance and emissions of a constant speed DI diesel engine fueled with pentanol/diesel blends. Fuel, 160, 217-226.

[78] Yilmaz, N. (2012). Effects of intake air preheat and fuel blend ratio on a diesel engine operating on biodieselmethanol blends. Fuel, 94, 444-447.

[79] Candan, F., Ciniviz, M., and Örs, İ. (2017). Effect of cetane improver addition into diesel fuel methanol mixtures on performance and emissions at different injection pressures. Thermal Science, 21(1B), 555-566.

[80] Cheung, C. S., Di, Y., and Huang, Z. (2008). Experimental investigation of regulated and unregulated emissions from a diesel engine fueled with ultralow-sulfur diesel fuel blended with ethanol and dodecanol. Atmospheric Environment, 42(39), 8843-8851.

[81] Karabektas, M., and Hosoz, M. (2009). Performance and emission characteristics of a diesel engine using isobutanol-diesel fuel blends. Renewable Energy, 34(6), 15541559.

[82] Sharon, H., Ram, P. J. S., Fernando, K. J., Murali, S., and Muthusamy, R. (2013). Fueling a stationary direct injection diesel engine with diesel-used palm oil-butanol 
blends-an experimental study. Energy Conversion and Management, 73, 95-105.

[83] Balat, M., and Balat, H. (2008). A critical review of biodiesel as a vehicular fuel. Energy Conversion and Management, 49(10), 2727-2741.

[84] Ramadhas, A. S., Muraleedharan, C., and Jayaraj, S. (2005). Performance and emission evaluation of a diesel engine fueled with methyl esters of rubber seed oil. Renewable Energy, 30(12), 1789-1800.

[85] Akar, M. A. (2016). Performance and emission characteristics of compression ignition engine operating with false flax biodiesel and butanol blends. Advances in Mechanical Engineering, 8(2), 1-7.

[86] Alptekin, E., Canakci, M., Ozsezen, A. N., Turkcan, A., and Sanli, H. (2015). Using waste animal fat based biodiesels-bioethanol-diesel fuel blends in a DI diesel engine. Fuel, 157, 245-254.

[87] Atmanli, A. (2016). Comparative analyses of dieselwaste oil biodiesel and propanol, n-butanol or 1-pentanol blends in a diesel engine. Fuel, 176, 209-215.

[88] Li, L., Wang, J., Wang, Z., and Liu, H. (2015). Combustion and emissions of compression ignition in a direct injection diesel engine fueled with pentanol. Energy, 80, 575-581.

[89] Yusri, I. M., Mamat, R., Najafi, G., Razman, A., Awad, O. I., Azmi, W. H., Ishak, WFW, and Shaiful, A. I. M. (2017). Alcohol based automotive fuels from first four alcohol family in compression and spark ignition engine: A review on engine performance and exhaust emissions. Renewable and Sustainable Energy Reviews, 77, 169-181.

[90] Kumar, B. R., Saravanan, S., Rana, D., and Nagendran, A. (2016). A comparative analysis on combustion and emissions of some next generation higher-alcohol/diesel blends in a direct-injection diesel engine. Energy Conversion and Management, 119, 246-256.

[91] Yilmaz, N., and Atmanli, A. (2017). Experimental assessment of a diesel engine fueled with diesel-biodiesel1-pentanol blends. Fuel, 191, 190-197.

[92] Ileri, E., Atmanli, A., and Yilmaz, N. (2016). Comparative analyses of n-butanol-rapeseed oil-diesel blend with biodiesel, diesel and biodiesel-diesel fuels in a turbocharged direct injection diesel engine. Journal of the Energy Institute, 89(4), 586-593.

[93] Bergthorson, J. M., and Thomson, M. J. (2015). A review of the combustion and emissions properties of advanced transportation biofuels and their impact on existing and future engines. Renewable and Sustainable Energy Reviews, 42, 1393-1417.

[94] Atmanli, A., and Yilmaz, N. (2018). A comparative analysis of n-butanol/diesel and 1-pentanol/diesel blends in a compression ignition engine. Fuel, 234, 161-169.

[95] Altun, S., Oner, C., Yasar, F., and Adin, H. (2011). Effect of n-butanol blending with a blend of diesel and biodiesel on performance and exhaust emissions of a diesel en- gine. Industrial and Engineering Chemistry Research, 50(15), 9425-9430.

[96] Anderson, A., Devarajan, Y., and Nagappan, B. (2018). Effect of injection parameters on the reduction of NOx emission in neat bio-diesel fuelled diesel engine. Energy Sources, Part A: Recovery, Utilization, and Environmental Effects, 40(2), 186-192.

[97] Imdadul, H. K., Masjuki, H. H., Kalam, M. A., Zulkifli, N. W. M., Alabdulkarem, A., Rashed, M. M., Teoh, YH, and How, H. G. (2016). Higher alcohol-biodiesel-diesel blends: an approach for improving the performance, emission, and combustion of a light-duty diesel engine. Energy Conversion and Management, 111, 174185.

[98] Nalgundwar, A., Paul, B., and Sharma, S. K. (2016). Comparison of performance and emissions characteristics of DI CI engine fueled with dual biodiesel blends of palm and jatropha. Fuel, 173, 172-179.

[99] Mahalingam, A., Munuswamy, D. B., Devarajan, Y., and Radhakrishnan, S. (2018). Emission and performance analysis on the effect of exhaust gas recirculation in alcohol-biodiesel aspirated research diesel engine. Environmental Science and Pollution Research, 25(13), 12641-12647.

[100] Shu, J., Fu, J. Q., Liu, J. P., Zhang, L., and Zhao, Z.C. (2018). Experimental and computational study on the effects of injection timing on thermodynamics, combustion and emission characteristics of a natural gas (NG)-diesel dual fuel engine at low speed and low load. Energy Conversion and Management, 160, 426-438.

[101] Yesilyurt, M. K., Eryilmaz, T., and Arslan, M. (2018). A comparative analysis of the engine performance, exhaust emissions and combustion behaviors of a compression ignition engine fuelled with biodiesel/diesel/1-butanol (C4 alcohol) and biodiesel/diesel/n-pentanol (C5 alcohol) fuel blends. Energy, 165, 1332-1351.

[102] Devarajan, Y., Munuswamy, D., Nagappan, B., and Subbiah, G. (2019). Experimental assessment of performance and exhaust emission characteristics of a diesel engine fuelled with Punnai biodiesel/butanol fuel blends. Petroleum Science, 16(6), 1471-1478.

[103] Xing-cai, L., Jian-Guang, Y., Wu-Gao, Z., and Zhen, H. (2004). Effect of cetane number improver on heat release rate and emissions of high speed diesel engine fueled with ethanol-diesel blend fuel. Fuel, 83(14-15), 20132020.

[104] Rakopoulos, D. C., Rakopoulos, C. D., Giakoumis, E. G., Dimaratos, A. M., and Kyritsis, D. C. (2010). Effects of butanol-diesel fuel blends on the performance and emissions of a high-speed DI diesel engine. Energy Conversion and Management, 51(10), 1989-1997.

[105] Emiroğlu, A. O., and Şen, M. (2018). Combustion, performance and emission characteristics of various alcohol blends in a single cylinder diesel engine. Fuel, 212, 3440. 
[106] Abu-Qudais, M., Haddad, O., and Qudaisat, M. (2000). The effect of alcohol fumigation on diesel engine performance and emissions. Energy Conversion and Management, 41(4), 389-399.

[107] Yao, M., Wang, H., Zheng, Z., and Yue, Y. (2010). Experimental study of n-butanol additive and multiinjection on HD diesel engine performance and emissions. Fuel, 89(9), 2191-2201. 